Ilhom Abdulloev, Gil S. Epstein and Ira N. Gang

\title{
Migration and Forsaken Schooling in Kyrgyzstan, Tajikistan, and Uzbekistan
}

\begin{abstract}
Large international earnings differentials negatively impact human capital investments in migrant-origin countries. We find that three Central Asian migrant-sending countries-the Kyrgyz Republic, the Republic of Tajikistan, and the Republic of Uzbekistan-are facing a forsaken schooling phenomenon. Once completing their compulsory schooling, young people in these countries are forsaking additional schooling because of opportunities to migrate to high-paying low-skilled jobs in the Russian Federation. The countries face a loss in human capital formation.
\end{abstract}

$\begin{array}{ll}\text { Current version: } & \text { January 21, } 2020 \\ \text { Keywords: } & \text { migration; poverty; inequality; education; skill } \\ \text { JEL Codes: } & \text { O15, P46, F22, I24 } \\ \text { Corresponding author: } & \text { Ilhom Abdulloev } \\ & \text { ailhom@hotmail.com }\end{array}$

Open Society Institute Assistance Foundation - Tajikistan (OSIAF), 37/1 Bokhtar Street, Dushanbe 734002, Tajikistan. E-mail: ailhom@hotmail.com

Department of Economics, Bar-Ilan University, 52900 Ramat-Gan, Israel. E-mail: gil.epstein@biu.ac.il. Tel: + 972528550 407, fax: +97235353180.

Department of Economics, Rutgers University, 75 Hamilton Street, New Brunswick NJ 08901-1248, USA. E-mail: gang@rutgers.edu. Tel: +1 848-732-8648, fax: +1 732-932-7416.

(c) The Author(s). 2020 Open Access This article is distributed under the terms of the Creative Commons Attribution 4.0 International License (http://creativecommons.org/licenses/by/4.0/), which permits unrestricted use, distribution, and reproduction in any medium, provided you give appropriate credit to the original author(s) and the source, provide a link to the Creative Commons license, and indicate if changes were made. @- Cite as: Abdulloev et al. IZA Journal of Development and Migration (2020) 11:4. 


\section{Introduction}

The phenomenon of forsaken schooling results from very large earnings differentials between potential migrants' host and home countries. The opportunity to migrate to high-paying often low-skilled jobs (regardless of schooling) leads to reduced home country educational investment as people forgo schooling beyond enforced compulsory levels. In this article, we examine forsaken schooling in three Central Asian countries, which are supplying labor migrants to the Russian Federation.

Abdulloev et al. (2019) look at Tajikistan's professional education and migration decisions, finding that with existing international wage differentials for low-skilled labor in higher-income Russia, individuals and families in migrant-sending Tajikistan may forgo professional or continued education. Instead, they opt to migrate to high-paying unskilled jobs in Russia, especially when those jobs are paying multiples of their home pay, even for skilled migrants taking unskilled host-country jobs. Such an income gap may lead to the rejection of professional education and training by individuals in the migrants' origin country in expectation of migration. Where the existence of high-paying low-skilled jobs abroad reduces educational investment at home, this can give rise to a forsaken schooling phenomenon in migration. Forsaken schooling caused by migration opportunities would limit the extent to which the studied countries could reap demographic dividends employing internally these individuals, especially if they had studied more. In this article, we examine this phenomenon with regard to all three migrant-sending countries of Central Asia-Kyrgyzstan, Tajikistan, and Uzbekistan.

Section 2 provides a literature review focusing on the role migration that may play in schooling decisions in these three former Soviet countries in Central Asia. Section 3 describes the schooling systems in Kyrgyzstan, Tajikistan, and Uzbekistan. Section 4 provides information about the data and variables used in our analysis and elaborates a potential mechanism of the relationship between migration and education status. Section 5 provides our econometric model and estimation results, with an analysis of the phenomenon and several empirical robustness checks. Section 6 concludes by recounting the structure of our approach to answering our key questions: what effect does the availability of highly paid low-skilled jobs abroad have on education decisions of individuals in countries characterized by strong outmigration flows? Can the existence of migration opportunities lead to the phenomenon of forsaken schooling, with potentially negative socioeconomic consequences?

\section{Literature review}

Over the past several decades, the concepts of brain-drain and brain-gain have dominated the discussion of the effects on the home country of the highly schooled emigrating abroad. The brain-drain highlights the negative direct impacts of skilled/educated emigration on those left behind, not necessarily the immediate family for whom there is a direct and obvious trade-off, but the whole economy (Bhagwati and Hamada, 1974; Grubel and Scott, 1966). The brain-gain emphasizes second-round positive impacts on the source country of international emigration through remittances, enhanced returned migrants' skills (Co et al., 2000; Dai et al., 2015), and skills acquisition by those intending to migrate (Beine et al., 2008). Moreover, while papers 
find that education is not a major determinant of the likelihood of sending remittances, conditional on sending remittances migrants with a university degree send more than those with less schooling (Bredtmann et al., 2019).

Kandel and Kao (2001) found a negative association for children in Mexico between frequency of Mexico-USA migration and tertiary education, leading them to argue that the expectation of future migration and no reward for Mexican education on the US job market discourages young people from continuing their education beyond the junior or senior high school levels in Mexico. McKenzie and Rapoport (2011) found that boys in migrant families in Mexico are less likely to complete junior high school or high school and are more likely to migrate, while girls in migrant families are less likely to complete high school and more likely to do housework. There is also a discussion of a brain-waste phenomenon when immigrants work at lesser-skilled jobs than their home country training would imply (Weiss et al., 2003; Özden, 2006).

This compares with studies that emigration induces more human capital formation in home countries (Mountford, 1997; Stark et al., 1997, 1998; Stark and Wang, 2002; Edwards and Ureta, 2003; Piracha et al., 2013; Hines and Simpson, 2018). Migrant's household members may use remittances to boost educational attainment as migrant families can afford to pay school fees, transportation, and school essentials, or hire labor to work in households, businesses, and farms. This frees children from such work, allowing them to continue their education (Dimova et al., 2015; Duryea et al., 2003; Acosta, 2006; Calero et al., 2009; Amuedo-Dorantes and Pozo, 2010; Yang, 2005). Beine, Docquier and Rapoport $(2001,2008)$ suggesting that emigration might lead to a "beneficial brain-drain" through a "demonstration effect" if the benefits of increased investments in education exceed the costs of skilled labor emigration.

We examine three Central Asian republics-Kyrgyzstan, Tajikistan, and Uzbekistan. All three are major migrant-sending countries to the Russian Federation. This migration is a relatively new phenomenon as these countries were formerly part of the Soviet Union, which generally restricted migration. After the Union's dissolution, countries with large natural resource endowments (Russia, Kazakhstan, and Turkmenistan), industries (Ukraine and Belarus), and favorable geographical location (Lithuania, Estonia, and Latvia) achieved comparatively good economic performance. After an initial large drop, their real wages grew relatively rapidly, while wages grew more slowly in more labor-abundant countries such as Kyrgyzstan, Tajikistan, and Uzbekistan. The income differential between Russia and these Central Asian countries along with free (no-visa) entry policies attract many of their economically active populations to Russia. ${ }^{1}$ Remittances and migration play an important augmenting role in the lives of families in these countries: migrants' households fund a significant portion of their consumption through remittances.

The issue of migration and educational attainment in Central Asian countries has been the focus of several studies. Danzer et al. (2013) report that the large share of Tajikistani migrants (approximately 60\%) has general secondary education but no additional professional education. Gatskova et al. (2019) found that the effect of migration on girls' school attendance differs by age in families with migrants: school attendance improves for ages 7-11 but falls for ages 12-17. The latter is when preparation for professional (post-secondary school) education

1 Extreme pay gaps exist and can be sustained over the long term as argued by Kravis and Lipsey (1983), Bhagwati (1984), Panagariya (1988), and Feldman and Gang (1990). 
takes place. Kroeger and Anderson (2014) found that international remittances do not have a significant positive impact on the school enrollment of children from migrants' families in Kyrgyzstan but instead decreases schooling for 14-18 boys as they have to contribute more of their time to household and market work in the absence of migrant members of the household. Gao and Kikkawa (2019), using 5-year panel data from Kyrgyzstan, found a negative impact of remittances on educational achievement and investment-remittances are mainly spent on durable goods, not on education. Moreover, the missing adult migrant can increase children's participation in farm work while decreasing school attendance. Ahunov et al. (2015) did not find a significant income effect for remittances on educational spending in Uzbekistan. Wang et al. (2019) also found that remittances have no effect on investment in education and housing; rather than leading to reduced food expenditure and increased medical expediture. Yamada (2016) found that if current migration is associated with an investment in compulsory education for poor households, past migration experience has a negative effect on compulsory education for nonpoor households and noncompulsory education for all households in Tajikistan.

A series of World Bank Skills Road reports (Ajwad et al., 2014a; 2014b; 2014c) show that those planning to migrate have on average better cognitive and noncognitive skills than others in the working-age population. Similarly, returned migrants have significantly higher cognitive and noncognitive skill outcomes than nonmigrants. Both results suggest that migrants do not necessarily acquire additional cognitive skills during their stay abroad.

\section{Schooling and choice in Kyrgyzstan, Tajikistan, and Uzbekistan}

Kyrgyzstan, Tajikistan, and Uzbekistan inherited a socialist education system that guaranteed free basic education. All children are required to attend elementary schools at age 6-7 and guaranteed free compulsory education: 9 years in Kyrgyzstan (changed to 10 in 2014) and Tajikistan, 12 years in Uzbekistan. After completing their general education at ages 16-18, a young adult can choose to either enter the labor force or continue their schooling. Schooling up to this point is compulsory and includes primary education (grades 1-4) and basic education (grades 5-9) for Tajikistan and Kyrgyzstan, and the secondary education (grades 10-12) in Uzbekistan. The ambiguity of the final grade here depends on the month of birth.

If the young adult decides to continue their schooling, they can follow several paths. They may choose continued study for two more years to complete (upper) secondary education. Its completion provides the entry requirements for tertiary education. Alternatively, a young adult may choose to enter primary or secondary professional education. Lyceums and vocational schools provide primary professional education; technical schools and colleges provide secondary professional education. Universities offer higher tertiary education, where students pursue bachelors, masters, and $\mathrm{PhD}$. Figure 1 lays out the structure of Tajikistan's educational system, the translation of degrees into years of schooling, and the normal corresponding students' ages.

Some units offering professional schooling had difficulty delivering it after the Soviet era. State-owned vocational schools (lyceums and colleges) faced major problems in moving from socialist to market-based systems. These schools operated with major contributions to the schools' curricula, equipment and internship programs from specific state-owned enterprises 
Figure 1 Schooling, age, and degrees in Tajikistan.

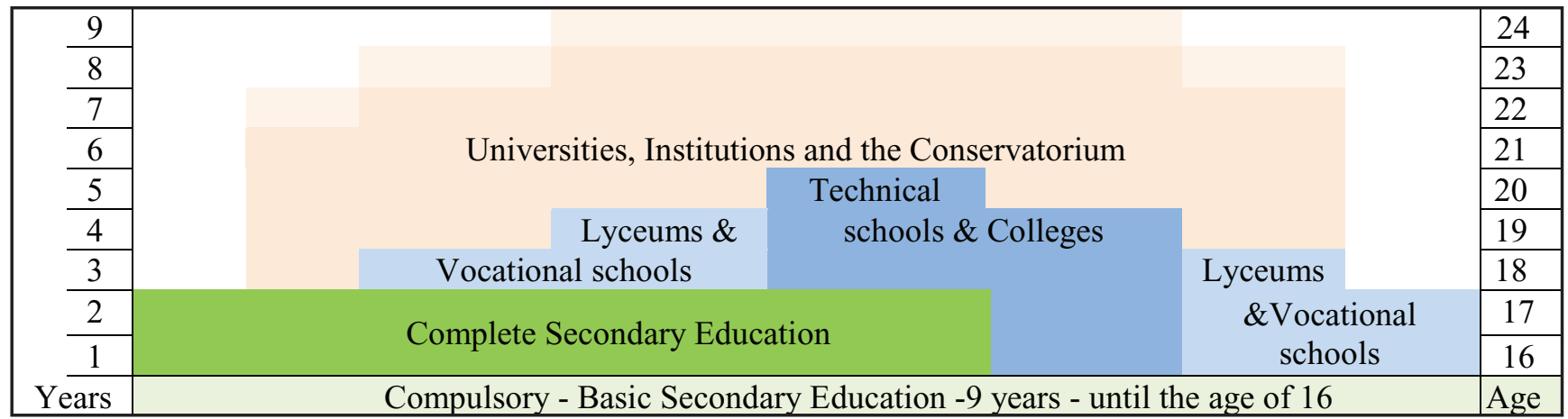

Note: This figure lays out the structure of Tajikistan's educational system, the translation of degrees into years of schooling, and the normal corresponding students' ages. In this article, professional education starts at years of schooling category "Professional lyceums and Vocational schools" corresponding to age 16 or 9 years of compulsory basic education. These are the lower band for the professional education categories. With professional education from lyceums and vocational schools, people work at lower professional occupations.

(SOEs) during the Soviet era. After the privatization of SOEs, vocational schools lost these linkages and have needed to rely on either state support or provide new market-oriented educational services. Lack of interest from private companies in the schools' services, and contracting support from the state, contributed to outdated curricula and equipment; these schools became less popular among the young.

Tertiary schools (universities), in contrast, improved in both curricula and equipment. With the help of international donors and private investors, tertiary schools undertook significant reforms and began providing educational services for pay. They increased their branches in both urban and rural areas, adding to competition and improving services. By establishing good relations and internship programs with various employers, as well as good job placement, the tertiary schools in contrast to vocational schools have gained popularity among the young, and their graduates enjoy better social status (Ajwad et al., 2014a, 2014b; 2014c).

Although the schooling systems in these countries are similar in history, there are some differences worth noting. Compulsory education in Uzbekistan is 12 years, in Kyrgyzstan is 9 years (10 starting from 2014), and in Tajikistan is 9 years. Kyrgyzstan has more private higher education institutes and a higher ratio of tertiary students to the total population. With a population of 5.9 million (2015), Kyrgyzstan has 53 higher education institutions, out of which 19 are private. The number of enrolled students in the 2013/2014 academic year was 214.4 thousand, with 188.7 thousand in public and 25.6 thousand in private institutes. Uzbekistan has a larger population of 31 million people (2015) and 82 higher education institutes. All institutes are public, and there is no private higher education institute in Uzbekistan. The number of enrolled students is 260.9 thousand in the academic year of 2014/2015. With a 2015 population of 8.4 million, Tajikistan had 39 higher education institutes, only one of which is private. The number of enrolled students is 157.8 thousand people, with 1.4 thousand studying in the private institute. ${ }^{2}$

2 See Education, Audiovisual and Culture Executive Agency of the European Union (2017). 
So, what is the role that migration plays in educational choice and how might this vary with the amount of schooling? Jobs reward workers not only with earnings but also with convey reputation and status. We can think about a simplified circumstance where the highest schooling achievers obtain status and reputation, while the middle achievers do not. ${ }^{3}$ The greater the reputation and status that a worker obtains from jobs requiring higher schooling levels, the more people will obtain higher education. This, of course, takes time and the higher their time preference, people place less weight on the future and care more about the present. In this case, people may forego the schooling and eventual high-status positions. Of course, if the status, reputation, and income one receives in a high-skilled job is high enough, people will stay in school. Instead, what if the low-skilled wage abroad (say in Russia) is very high compared to low- and high-skilled jobs in the home country? If the income of a nonprofessional worker in the host country is higher than in the home country, then an increasing migration probability will increase the chances an individual will choose a nonprofessional educational track. If host-country wages exceed those of home country high-skilled, the move away from higher schooling is further exacerbated.

Workers in professional fields may face a "wage penalty" as a result of job mismatch. A recent study on Kyrgyzstan indicates that young people with tertiary education are more likely to be employed in jobs that do not match their professional education and face a "wage penalty," receiving lower wages than those with whose education matches their jobs (Karymshakov and Sulaimanova, 2019). If such a wage penalty decreases expected earnings, the individual will decide not to obtain professional qualifications. Our major argument is that the choice between migration and acquiring tertiary education is driven by the wages for professional and nonprofessional workers in migrant destination and origin countries. These wages are determined by current labor market conditions in these countries, both by supply and demand sides. In footnote 1 , we cite established literature that argues that persistent international wage differentials may exist even when most of the standard assumptions of international trade and migration theory hold. The mismatch between schooling quality and what the labor market wants to reward may be the cause of low professional wages in the origin country, but it is only one of several possible explanations. For our story to work, we only need that there is an international difference in wages. Having the option of migrating, people can choose to migrate and work abroad for higher wages, forgoing additional education.

The large share of women in these predominantly Muslim countries remains outside of the migration stream and, at the same time, does not obtain professional schooling. This is explained by existing social norms that relate to concepts of femininity and masculinity in these countries. Labor migration from the Muslim societies of the Central Asia reflects traditional norms in which men are expected to be good sons, husbands, and fathers, earning enough to feed their families who stay in their home societies. Women are generally expected to stay home and look after children and elders (Rocheva and Varshaver, 2018). Therefore, the forsaken schooling phenomenon among women in Kyrgyzstan, Tajikistan, and Uzbekistan can be explained by existing social stigmas and norms in their respected societies but is not one made by choice. ${ }^{4}$

3 See Abdulloev, Epstein and Gang (2019) for a complete specification.

4 However, see the documentary, directed by Shakirov (2009) “Migrant Express," Parts 1-7. 


\section{Data}

To study the choice decision between professional education and migration, we use fresh data from the unique Jobs, Skills, and Migration Surveys. These surveys were implemented jointly by a team from the World Bank and the German Society for International Cooperation (GIZ) in three Central Asian republics, Kyrgyzstan, Tajikistan, and Uzbekistan in 2013 (Ajwad et al., 2014a, 2014b, 2014c). The surveys collect comprehensive information at the individual and household levels and are represented at the national, regional, and urban/rural levels. Combining the information from the three countries into a single cross-country survey, the sample size for the core questionnaire is 6,300 households with 35,770 individuals.

We limited our sample to respondents 25-39 years old who received their professional education after the collapse of the Soviet Union, as we want to distinguish between schooling and migration decisions in market economies. By age 25, an individual normally finishes his/ her professional education (either vocational or tertiary) and decides on employment. The upper age limit of 39 (i.e., 17 years old in 1991) is defined so that we are looking at the choice between migration and schooling after the collapse of the Soviet Union in 1991 (as migration within the Soviet Union was strictly controlled and even prohibited by the central government). The countries have also undergone a severe economic transformation from plan-based to market economies. As a result of both the collapse of the Union and economic transformation, many formerly state-owned enterprises have lost their value chain linkages with other republics' enterprises, and many enterprises were privatized. Factors influencing decisions on acquiring professional education during the Soviet time (wages were almost the same across the Union) differ from the post-Soviet ones. Our total sample size is 8,037 people, with 1,893 current and former migrants (22.39\%) and 6,144 nonmigrants. Migrants are those individuals whoever migrated for work abroad, including those who are currently working abroad or have returned to their home countries. Russia remains the major destination country for migrants from Tajikistan, Kyrgyzstan, and Uzbekistan: 90.26\% of current international migrants are in Russia, 8.57\% of current migrants are in Kazakhstan, and only $1.17 \%$ of current migrants live in other countries.

Table 1 provides the definitions of variables that we use in our analysis. Levels of education are defined as the highest completed education for which an individual has obtained a diploma or is currently enrolled. These education variables are aggregated into two: vocational education including secondary special or technical, and tertiary education including higher or graduate.

To examine the effect of migration on education, we use the categorical variable that identifies whether an individual is a former or current migrant, or not. A former migrant is an individual who migrated outside the country for work without coming back for at least 3 months. A current migrant is a person who is currently abroad.

Migrants from Kyrgyzstan, Tajikistan, and Uzbekistan migrate mainly for employment reasons, and many are not willing to attend any professional training in destination countries. This factor helps us to verify the existence of forsaken schooling in migration when the person chooses to migrate as a nonprofessional worker and does not acquire any professional training at home or even in the destination countries. ${ }^{5}$

5 We checked the question in the Skills (KISH) section of the survey about the skills training attended by migrants in the destination countries: out of 268 migrants in the KISH section, no one has attended skills training in destination country, and only nine people attended skills training in their home countries. 
Table 1 Description of variables

\begin{tabular}{|c|c|}
\hline Variable name & Description \\
\hline No education & A dummy variable taking a value of 1 if a person has no education and 0 otherwise. \\
\hline Primary education & $\begin{array}{l}\text { A dummy variable taking a value of } 1 \text { if a person's highest obtained/acquiring } \\
\text { educational level is primary education (grades 1-4) and } 0 \text { otherwise. }\end{array}$ \\
\hline Basic education & $\begin{array}{l}\text { A dummy variable taking a value of } 1 \text { if a person's highest obtained/acquiring } \\
\text { educational level is basic education (grades 5-8(9)) and } 0 \text { otherwise. }\end{array}$ \\
\hline $\begin{array}{l}\text { Secondary general } \\
\text { education }\end{array}$ & $\begin{array}{l}\text { A dummy variable taking a value of } 1 \text { if a person's highest obtained/acquiring } \\
\text { educational level is secondary general education (grades } 9-10(11) \text { ) and } 0 \text { otherwise. }\end{array}$ \\
\hline Vocational education & $\begin{array}{l}\text { A dummy variable taking a value of } 1 \text { if a person's highest obtained/acquiring educa- } \\
\text { tional level is vocational education (secondary special or technical) and } 0 \text { otherwise. }\end{array}$ \\
\hline Tertiary education & $\begin{array}{l}\text { A dummy variable taking a value of } 1 \text { if a person's highest obtained/acquiring } \\
\text { educational level is tertiary education (higher or graduate) and } 0 \text { otherwise. }\end{array}$ \\
\hline Household head & $\begin{array}{l}\text { A dummy variable taking a value of } 1 \text { if a person is the head of the household and } 0 \\
\text { otherwise. }\end{array}$ \\
\hline Former or current migrant & A dummy variable taking a value of 1 if a person has ever migrated and 0 otherwise. \\
\hline Married/nikoh & A dummy variable taking a value of 1 if a person is married and 0 otherwise. \\
\hline Age & The age of the person \\
\hline Age-square & The square of the age of the person \\
\hline Male & A dummy variable taking a value of 1 if a person is male and 0 otherwise. \\
\hline Female & A dummy variable taking a value of 1 if a person is female and 0 otherwise. \\
\hline Lives in capital & A dummy variable taking a value of 1 if a person lives in the capital and 0 otherwise. \\
\hline Lives in other urban areas & $\begin{array}{l}\text { A dummy variable taking a value of } 1 \text { if a person lives in other than capital urban } \\
\text { area and } 0 \text { otherwise. }\end{array}$ \\
\hline Lives in a rural area & A dummy variable taking a value of 1 if a person lives in a rural area and 0 otherwise. \\
\hline Lives in Tajikistan & A dummy variable taking a value of 1 if a person lives in Tajikistan and 0 otherwise. \\
\hline Lives in Uzbekistan & A dummy variable taking a value of 1 if a person lives in Uzbekistan and 0 otherwise. \\
\hline Lives in Kyrgyzstan & A dummy variable taking a value of 1 if a person lives in Kyrgyzstan and 0 otherwise. \\
\hline Number of children age $<18$ & A number of children with ages less than 18 in the household. \\
\hline $\begin{array}{l}\text { Female-headed } \\
\text { household }\end{array}$ & $\begin{array}{l}\text { A dummy variable taking a value of } 1 \text { if the head of household is female and } \\
0 \text { otherwise. }\end{array}$ \\
\hline $\begin{array}{l}\text { Household consumption: } \\
\text { first quintile }\end{array}$ & $\begin{array}{l}\text { A dummy variable taking a value of } 1 \text { if the household is in the lowest consumption } \\
\text { quintile and } 0 \text { otherwise. }\end{array}$ \\
\hline $\begin{array}{l}\text { Household consumption: } \\
\text { second quintile }\end{array}$ & $\begin{array}{l}\text { A dummy variable taking a value of } 1 \text { if the household is in the second consumption } \\
\text { quintile and } 0 \text { otherwise. }\end{array}$ \\
\hline $\begin{array}{l}\text { Household consumption: } \\
\text { third quintile }\end{array}$ & $\begin{array}{l}\text { A dummy variable taking a value of } 1 \text { if the household is in the middle consumption } \\
\text { quintile and } 0 \text { otherwise. }\end{array}$ \\
\hline $\begin{array}{l}\text { Household consumption: } \\
\text { fourth quintile }\end{array}$ & $\begin{array}{l}\text { A dummy variable taking a value of } 1 \text { if the household is in the fourth consumption } \\
\text { quintile and } 0 \text { otherwise. }\end{array}$ \\
\hline $\begin{array}{l}\text { Household consumption: } \\
\text { fifth quintile }\end{array}$ & $\begin{array}{l}\text { A dummy variable taking a value of } 1 \text { if the household is the highest consumption } \\
\text { quintile and } 0 \text { otherwise. }\end{array}$ \\
\hline $\begin{array}{l}\text { Community's migrant } \\
\text { network age }>46\end{array}$ & $\begin{array}{l}\text { A share of migrants among the adult population with ages } 47 \text { and higher in the } \\
\text { survey's population sampling unit. }\end{array}$ \\
\hline $\begin{array}{l}\text { Household's share of adults } \\
\text { age }>46 \text { with professional } \\
\text { education }\end{array}$ & $\begin{array}{l}\text { A share of adults with professional education with ages } 47 \text { and higher in the } \\
\text { household. }\end{array}$ \\
\hline
\end{tabular}


In our analysis, we use individual age, gender, whether a person is the head of the household and some household characteristics such as living in the country's capital or other urban areas. We also include variables defining the countries, number of children with age of less than 18 in the household, a variable defining whether the household's head is female, and the consumption quintiles and the share of tertiary educated among adults with age 47 and above in the household.

We start by showing the wages migrants faced in Russia in comparison with their home country. Using data from the 2013 Jobs, Skills, and Migration Surveys (described in the next section), in Figure 2, we compare the mean monthly wages of migrants currently working in the Russian Federation to wages of those who never migrated and remain and work in their home countries, Kyrgyzstan, Tajikistan, and Uzbekistan. In particular, we look at the mean of wages by education and sector. The mean differences in wages by education are statistically significant for all wages. Because of the small migrant sample in some sectors, the mean differences in wages are not statistically significant from zero for all sectors. This implies that Central Asian migrants working as unskilled workers earn more than professionals in their home countries do.

Table 2 reports sample statistics both for the overall sample and for migrant and nonmigrant subsamples. Migration in Central Asia is male-dominated; about $84.85 \%$ of migrants are men. In the nonmigrant sample, $59.16 \%$ are women. Share of female migrants is the highest in Kyrgyzstan, 35.02\% of former or current migrants are women. Female former or current migrants are $13.72 \%$ and $10.01 \%$ of migrants in Uzbekistan and Tajikistan. Levels of education are defined using dummy variables for individuals having completed or acquiring degrees. Comparing education levels shows that those with no education, primary or basic education mainly remains in their home country. In contrast to those with low schooling levels, a larger share of people with secondary or vocational (secondary special and technical) schooling are migrants. People with the highest schooling levels (degrees received from universities) tend to remain in their home country due to their higher social status and access to higher-income home country jobs. The sample statistics show an inverted-U relationship between education and migration. People at lower and higher levels of education do not migrate, while at middle levels (secondary) more people choose to migrate.

Figure 2 Mean wages between migrants in the Russian Federation and nonmigrants in their home countries (by education and sectors).

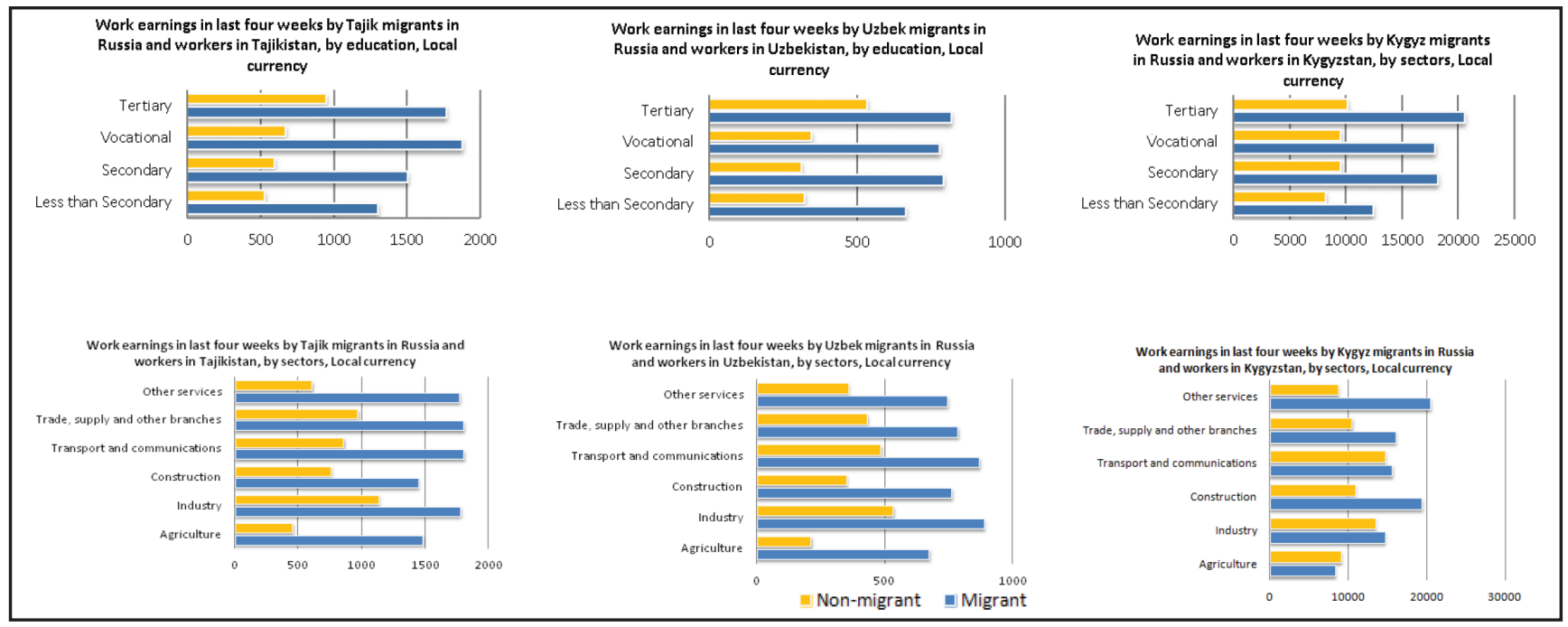




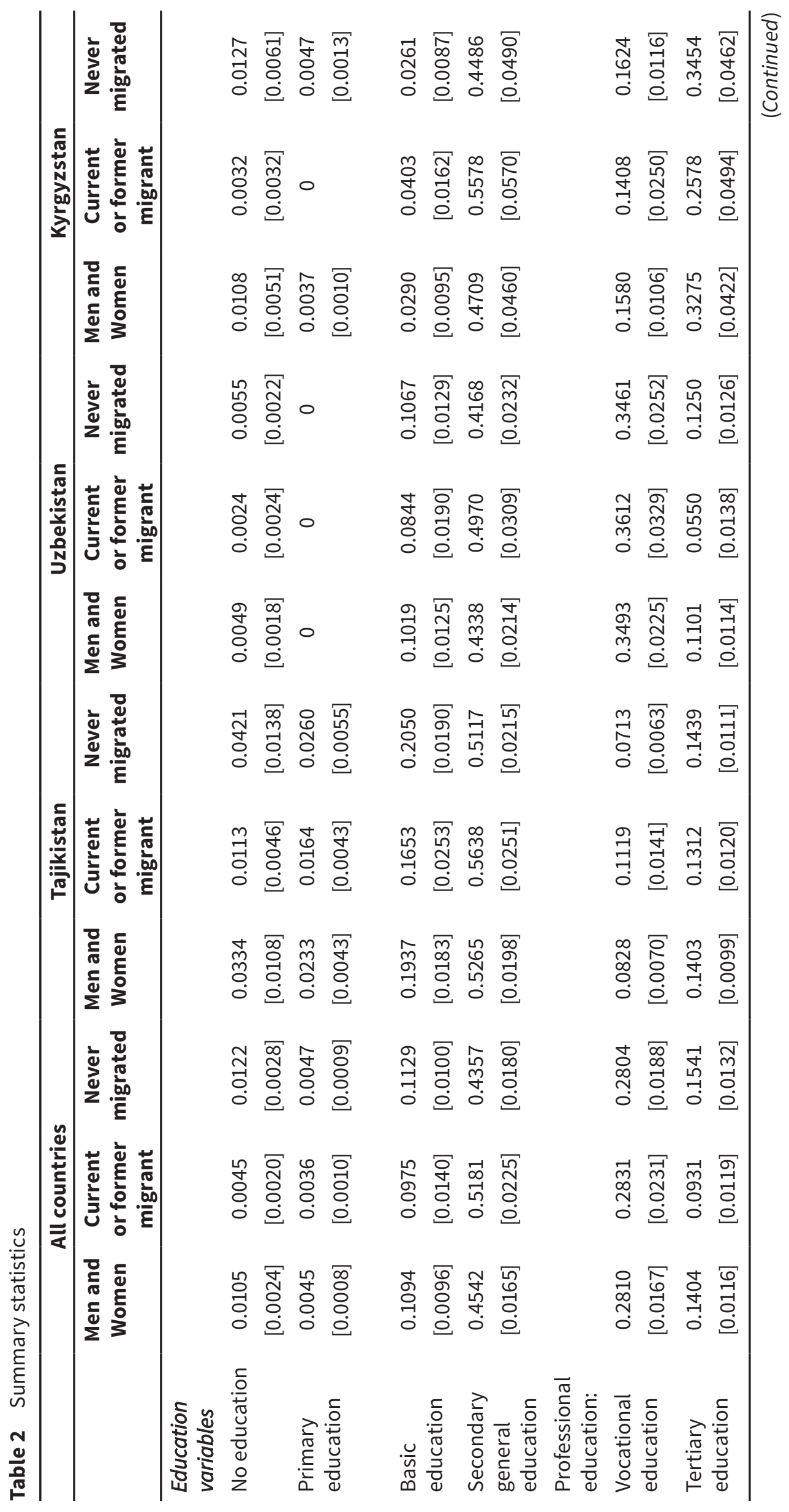




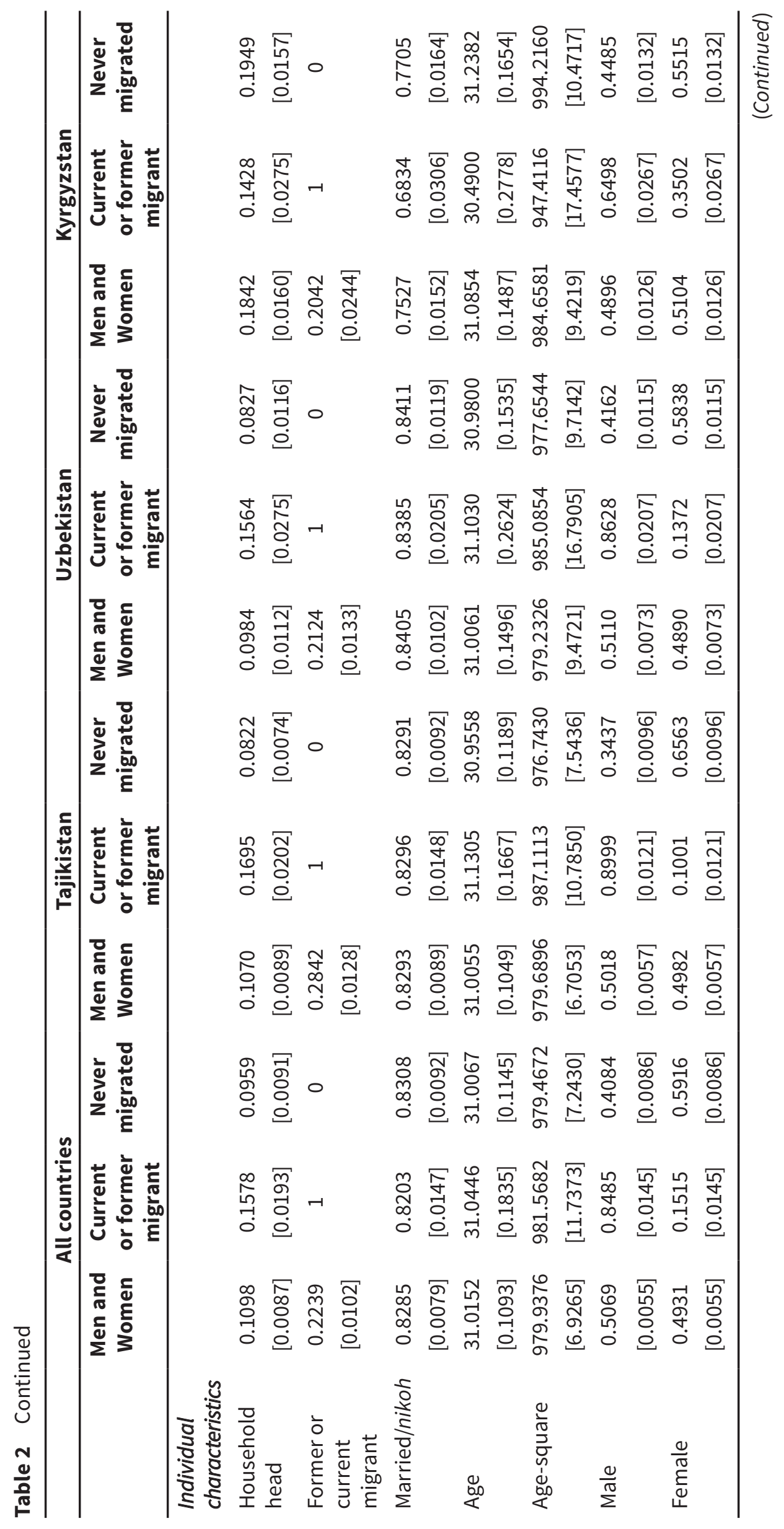




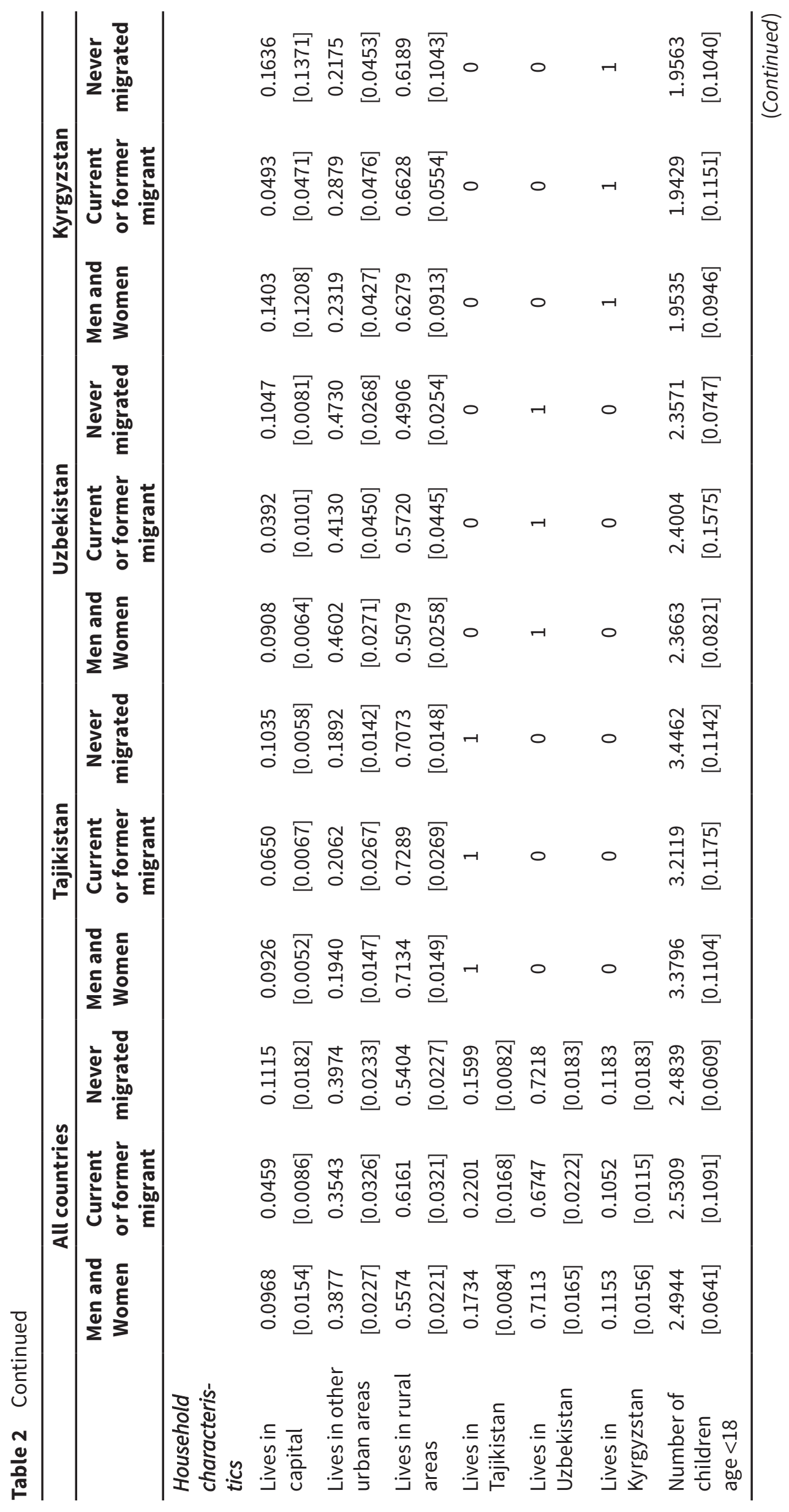




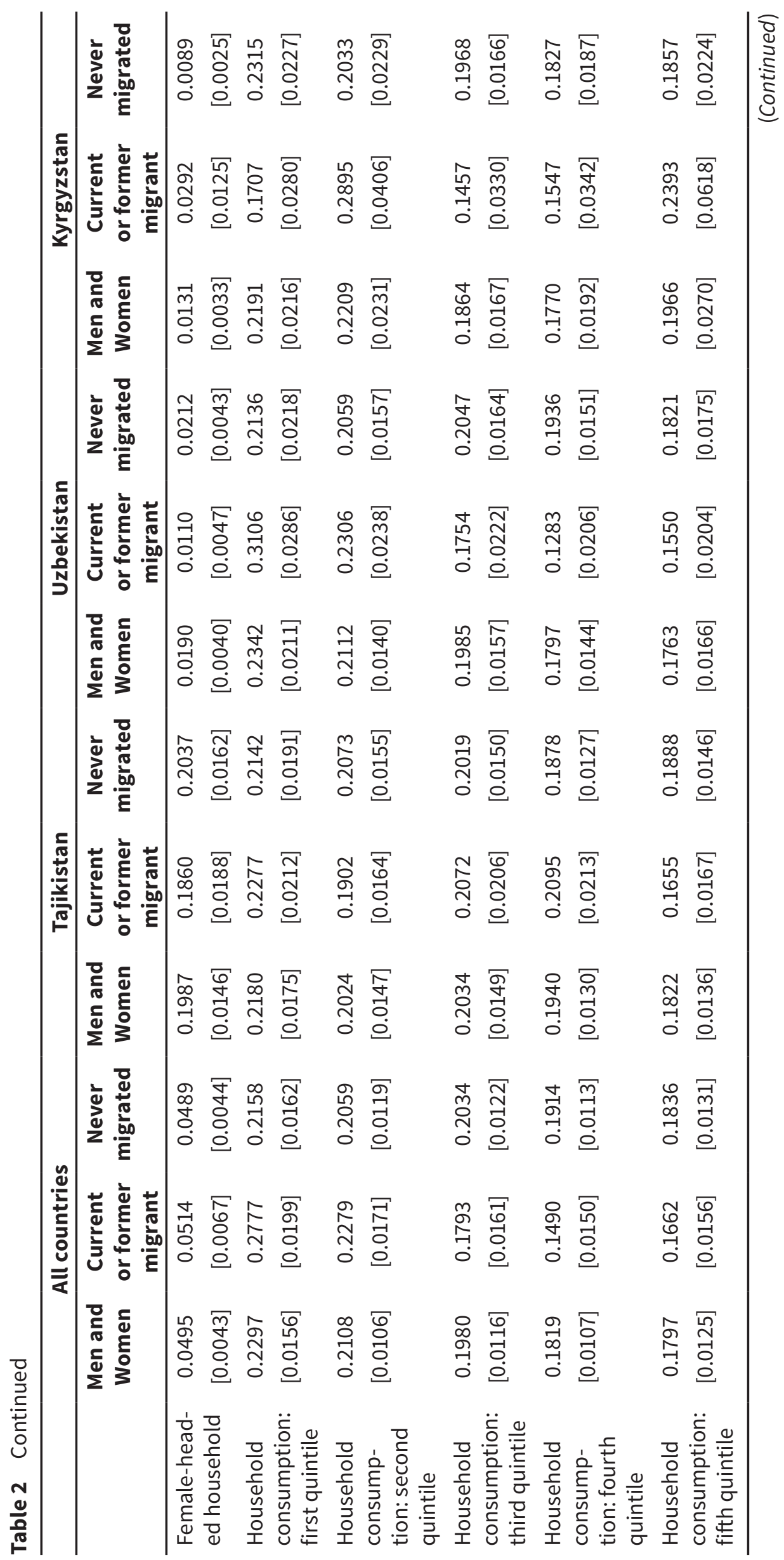




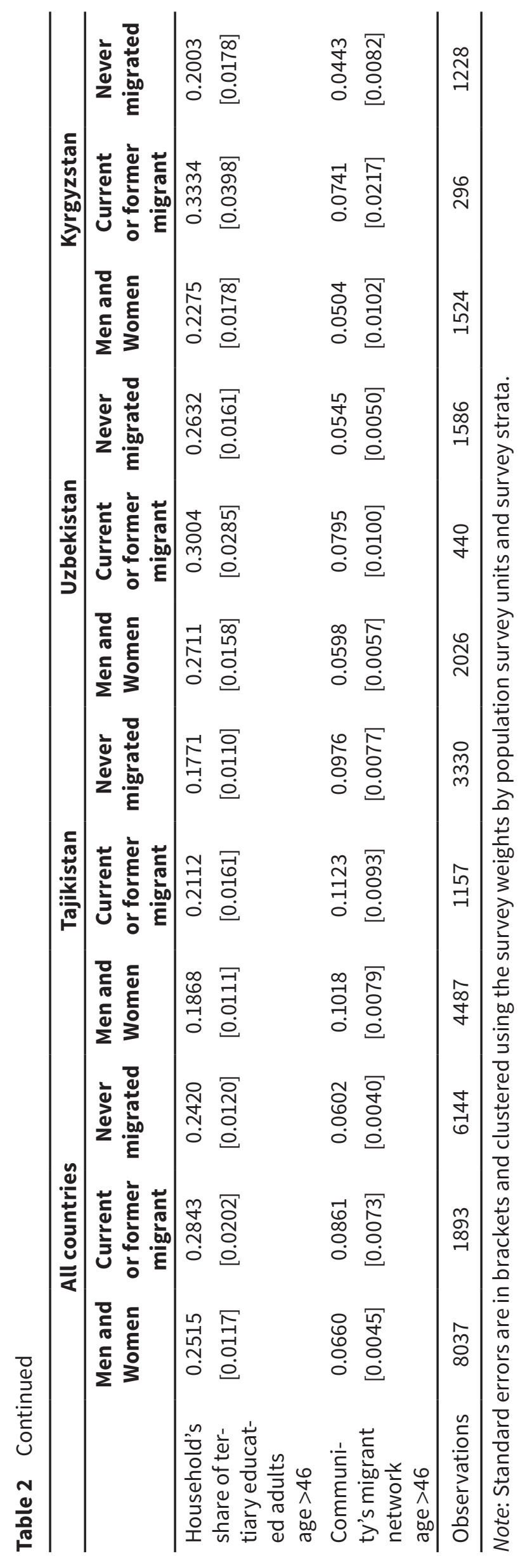


A cross-country comparison of the summary statistics shows that Tajikistan has a larger share of migrants relative to its population $28.42 \%$ (hence, the migrant network is larger in Tajikistan); these shares are 21.24\% in Uzbekistan and 20.42\% in Kyrgyzstan. At the same time, the shares of the population with vocational and tertiary education in Tajikistan are the lowest among the three countries: with $8.28 \%$ and $14.03 \%$, correspondingly. The shares of the population with vocational and tertiary education in Uzbekistan are $34.93 \%$ and $11.01 \%$, and in Kyrgyzstan, $15.80 \%$ and $32.75 \%$, correspondingly. The largest share of the population with tertiary education is in Kyrgyzstan, but the largest share of population with vocational education is in Uzbekistan. Such variations are manifestations of the different reforms implemented by these countries in the education sector.

\section{Econometric estimation}

We now turn to a more detailed look at our sample in order to study further the education-migration relationship. The forsaken schooling phenomenon occurs as low-skilled and skilled workers accept low-skilled positions in host countries, forgoing high professional schooling in their home country. We expect, therefore, migrants will not have completed professional schools (technical-vocational or tertiary). To verify this, we use the following econometric binary response models:

$$
\begin{aligned}
& \text { Ter.educ }_{\mathrm{i}}=1\left(\lambda_{0}+\lambda_{1} \operatorname{migr}_{\mathrm{i}}+\mathrm{X}_{1 \mathrm{i}} \Lambda+\mathrm{o}_{1}>0\right) \\
& \operatorname{migr}_{\mathrm{i}}=1\left(\pi_{0}+\pi_{1} \mathrm{z}_{\mathrm{i}}+\mathrm{X}_{1 \mathrm{i}} \Pi+\mathrm{v}_{\mathrm{i}}>0\right)
\end{aligned}
$$

where $i$ : individual, Ter.educ is a binary dependent variable that takes value of 1 if an individual has obtained/is obtaining tertiary education and zero otherwise, ò $\sim N(0, \Omega), X_{i}$ is a matrix of nonmigration-related variables affecting the decision to acquire tertiary education specified above (including the vector of ones) with coefficient vectors, $\Lambda$ and $\Pi$, of each equation correspondingly. migr $_{i}$ is a dichotomous variable defining the choice of migration. $z_{i}$ is an excluded exogenous variable defining variable migr $_{i}$. We use the community-based migrant network variable as the excluded exogenous variable. ${ }^{6}$ We restricted the migrant network to people with age of 47 and above as their decisions on acquiring education at the time of the Soviet Union were not affected by migration that was strictly controlled by the government. $\hat{\mathrm{U}}_{\mathrm{i}}, v_{i}$ has a zero mean with a bivariate normal distribution.

To estimate the migration's effect on tertiary (high) education choice, we estimate the first equation: the dependent variable in the probit is whether or not the respondent has completed or acquired tertiary education. The coefficients estimates and marginal effects are provided in Table 3. Independent variables are a dummy variable on whether an individual is a former or current migrant, variables on whether an individual is head of the household, his/her marital status, age, age-squared, and gender. We also included household characteristics, such as variables on the number of children in the household with age less than 18 , and whether the household lives in the rural areas (the reference group is living in urban areas), whether the

6 The sample data in Jobs, Skills, and Migration Surveys is grouped into population survey units (PSU), here called communities, which are geographical areas of a walkable size. Each PSU or community consists of most of 20 households. 
household is female-headed, and where the household is in the consumption quintile distribution. To control for unobserved country-level factors such as differences in education systems, income, geography, and so on, we include country dummies for Tajikistan and Uzbekistan (the reference country is Kyrgyzstan). To control the effect of parental and household elder cohorts' education on the decision to acquire tertiary education, we included the share of adults with professional education age 47 and above in the household. ${ }^{7}$ After controlling for country unobserved effects, we find a significantly negative correlation at the 0.01 significance level between being an international migrant worker and the decision to obtain tertiary education. Regardless of the country differences in educational systems, migrants from Kyrgyzstan, Tajikistan, and Uzbekistan choose not to obtain high professional education but instead to migrate. Other significant factors affect the choice of tertiary education: (1) a positive correlation with being male, as families choose to invest in the professional education of sons; (2) a positive correlation with being the head of the household; (3) a negative correlation with living in Uzbekistan and Tajikistan compared to Kyrgyzstan, which undertook successful educational reforms; (4) A negative correlation of living in rural areas due to difficulty accessing tertiary education there; (5) a positive correlation with households' consumption, richer families send their children for higher education; and (6) a positive correlation between the share of tertiary educated among adults with age 47 and above in the household and the decision to obtain higher education.

We now estimate a probit model on the individual's decision to migrate as an index function of acquired(ing) education level, vocation or tertiary (the reference group is no professional schooling, i.e., lower educational levels), and the same individual and household characteristics which we used in the probit model on the decision of acquiring tertiary education. To control for the community's exogenous effects, we include the community level migrant network as the share of current and former migrants (age 47 and above) in the community. The dependent variable is whether an individual is/was an international migrant worker versus those who never migrated. The coefficient estimates and their marginal effects for both samples are reported in Table 4.

Here, we find a negative relationship between tertiary education and the decision to migrate. This relationship is significant at the 0.01 significance level. The reference group is individuals who have not completed professional education, either vocational or tertiary $(4,989$ respondents). The coefficients on the vocational education dummy variable remain insignificant, while the coefficient on dummy for tertiary education remains negative and statistically significant at the 0.01 significance level. Migration in Central Asia is male-dominated, and the majority of migrants are from the rural areas; the coefficients and marginal effects of being a male or living in rural areas are positive and are statistically different from 0 at 0.01 and 0.05 significance levels, correspondingly. Living in female-headed households negatively correlates with the migration decision. Consumption quintile dummies (the reference is the lowest income quintile) indicate the negative relationship between consumption and the decision to migrate. People from middle-consumption families ( $3^{\text {rd }}-5^{\text {th }}$ quintiles) tend to remain in their home country; the corresponding coefficients are statistically significantly different from 0 at the 0.01 significance levels. The marginal effect for the fifth quintile is lower than the fourth quintile implying an inverted-U relationship between consumption and decision to migrate.

$7 \quad$ The survey does not ask a question about parental education. 
Table 3 Probit and heteroscedastic probit regressions on decision of tertiary education

\begin{tabular}{|c|c|c|c|c|c|}
\hline \multirow{2}{*}{$\begin{array}{l}\text { Completed tertiary education }=1 \text { (=0 if } \\
\text { lower education) }\end{array}$} & \multicolumn{2}{|c|}{ Probit model } & \multicolumn{3}{|c|}{ Heteroscedastic probit model } \\
\hline & Coefficients & $\begin{array}{l}\text { Marginal } \\
\text { effects }\end{array}$ & Coefficients & $\begin{array}{l}\text { Marginal } \\
\text { effects }\end{array}$ & Insigma2 \\
\hline \multirow[t]{2}{*}{ Former or current migrant } & $-0.4482^{\star \star \star}$ & $-0.0756^{\star \star \star}$ & -0.1283 & $-0.0679^{\star \star \star}$ & 0.0858 \\
\hline & {$[0.0762]$} & {$[0.0118]$} & {$[0.1940]$} & {$[0.0092]$} & {$[0.0722]$} \\
\hline \multirow[t]{2}{*}{ Household head } & $0.3281^{\star \star \star}$ & $0.0699^{* \star *}$ & 0.1382 & $0.0969^{\star \star \star}$ & -0.0458 \\
\hline & {$[0.1098]$} & {$[0.0259]$} & {$[0.2092]$} & {$[0.0151]$} & {$[0.0907]$} \\
\hline \multirow[t]{2}{*}{ Married/nikoh } & 0.0675 & 0.0126 & 0.0577 & $0.0180^{\star}$ & $-0.1217^{*}$ \\
\hline & {$[0.0713]$} & {$[0.0128]$} & {$[0.0898]$} & {$[0.0105]$} & {$[0.0684]$} \\
\hline \multirow[t]{2}{*}{ Age } & 0.125 & 0.0237 & 0.0247 & 0.0082 & -0.0544 \\
\hline & {$[0.1152]$} & {$[0.0221]$} & {$[0.0286]$} & {$[0.0156]$} & {$[0.0959]$} \\
\hline \multirow[t]{2}{*}{ Age-square } & -0.0022 & -0.0004 & -0.0004 & -0.0002 & 0.001 \\
\hline & {$[0.0018]$} & {$[0.0003]$} & {$[0.0005]$} & {$[0.0002]$} & {$[0.0015]$} \\
\hline \multirow[t]{2}{*}{ Male } & $0.2798^{\star \star \star}$ & $0.0532^{\star \star \star}$ & 0.1333 & $0.0841^{\star \star \star}$ & -0.0501 \\
\hline & {$[0.0662]$} & {$[0.0132]$} & {$[0.2006]$} & {$[0.0101]$} & {$[0.0738]$} \\
\hline \multirow[t]{2}{*}{ Lives in rural areas } & $-0.3144^{* \star \star}$ & $-0.0607^{\star \star \star}$ & -0.3076 & $-0.1517^{\star \star \star}$ & $0.3060^{\star \star \star}$ \\
\hline & {$[0.0963]$} & {$[0.0192]$} & {$[0.4700]$} & {$[0.0089]$} & {$[0.1057]$} \\
\hline \multirow[t]{2}{*}{ Lives in Tajikistan } & $-0.5272^{\star \star \star}$ & $-0.0859^{* \star \star}$ & -0.0312 & $-0.0976^{* \star \star}$ & $-0.5223^{\star \star \star}$ \\
\hline & {$[0.1011]$} & {$[0.0158]$} & {$[0.0586]$} & {$[0.0116]$} & {$[0.0926]$} \\
\hline \multirow[t]{2}{*}{ Lives in Uzbekistan } & $-0.9129^{\star \star \star}$ & $-0.2074^{\star \star \star}$ & -0.3173 & $-0.1938^{\star \star \star}$ & -0.1528 \\
\hline & {$[0.1051]$} & {$[0.0254]$} & {$[0.4876]$} & {$[0.0098]$} & {$[0.1131]$} \\
\hline \multirow[t]{2}{*}{ Number of children age $<18$} & -0.0305 & -0.0058 & -0.02 & $-0.0141^{\star \star \star}$ & -0.0031 \\
\hline & {$[0.0258]$} & {$[0.0047]$} & {$[0.0308]$} & {$[0.0025]$} & {$[0.0162]$} \\
\hline \multirow[t]{2}{*}{ Female headed household } & -0.1728 & $-0.0305^{*}$ & -0.1257 & $-0.0360^{* *}$ & $0.2324^{*}$ \\
\hline & {$[0.1094]$} & {$[0.0177]$} & {$[0.1974]$} & {$[0.0150]$} & {$[0.1264]$} \\
\hline \multirow[t]{2}{*}{ Household consumption: second quintile } & 0.0315 & 0.006 & 0.0792 & $0.0445^{\star \star \star}$ & -0.0773 \\
\hline & {$[0.0851]$} & {$[0.0164]$} & {$[0.1248]$} & {$[0.0160]$} & {$[0.0883]$} \\
\hline \multirow[t]{2}{*}{ Household consumption: third quintile } & $0.4027^{\star \star \star}$ & $0.0848^{\star \star \star}$ & 0.0946 & $0.0654^{\star \star \star}$ & -0.013 \\
\hline & {$[0.1096]$} & {$[0.0251]$} & {$[0.1458]$} & {$[0.0163]$} & {$[0.0899]$} \\
\hline \multirow[t]{2}{*}{ Household consumption: fourth quintile } & $0.4420^{\star * \star}$ & $0.0946^{* \star *}$ & 0.1178 & $0.0868^{\star \star \star}$ & 0.0121 \\
\hline & {$[0.1042]$} & {$[0.0255]$} & {$[0.1820]$} & {$[0.0169]$} & {$[0.0931]$} \\
\hline \multirow[t]{2}{*}{ Household consumption: fifth quintile } & $0.6035^{\star \star \star}$ & $0.1355^{\star \star \star}$ & 0.2009 & $0.1402^{\star \star \star}$ & -0.0907 \\
\hline & {$[0.0939]$} & {$[0.0243]$} & {$[0.3044]$} & {$[0.0180]$} & {$[0.0915]$} \\
\hline \multirow{2}{*}{$\begin{array}{l}\text { Household's share of tertiary educated } \\
\text { adults age }>46\end{array}$} & $0.7326^{\star \star \star}$ & $0.1391^{\star \star \star}$ & 0.255 & $0.1939^{\star \star \star}$ & 0.1277 \\
\hline & {$[0.0933]$} & {$[0.0172]$} & {$[0.3848]$} & {$[0.0119]$} & {$[0.0904]$} \\
\hline \multirow[t]{2}{*}{ Constant } & -2.55 & & -0.6308 & & \\
\hline & {$[1.8489]$} & & {$[0.7255]$} & & \\
\hline
\end{tabular}

Observations

8037

8037

Notes: Likelihood-ratio test of Insigma2 =0: $X^{2}(16)=89.59$; Prob $>X^{2}=0.0000 .{ }^{*} p<0.1 ;{ }^{* \star} p<0.05$; and ${ }^{\star \star *} p<0.01$. Standard errors are in brackets and clustered. Survey weights are only used in the Probit model by population survey units and survey strata. 
Table 4 Probit and heteroscedastic probit regressions on decision of migration

\begin{tabular}{|c|c|c|c|c|c|}
\hline \multirow{2}{*}{$\begin{array}{l}\text { Ever migrated abroad = } 1 \text { (=0 if never } \\
\text { migrated) }\end{array}$} & \multicolumn{2}{|c|}{ Probit model } & \multicolumn{3}{|c|}{ Heteroscedastic probit model } \\
\hline & Coefficients & $\begin{array}{c}\text { Marginal } \\
\text { effects }\end{array}$ & Coefficients & $\begin{array}{l}\text { Marginal } \\
\text { effects }\end{array}$ & Insigma2 \\
\hline \multirow[t]{2}{*}{ Vocational education } & -0.0011 & -0.0003 & -0.0020 & -0.0030 & 0.0860 \\
\hline & {$[0.0910]$} & {$[0.0221]$} & {$[0.0073]$} & {$[0.0116]$} & {$[0.0591]$} \\
\hline \multirow[t]{2}{*}{ Tertiary education } & $-0.4628^{\star \star *}$ & $-0.1013^{* * *}$ & -0.0149 & $-0.0880^{\star * \star}$ & $0.1153^{*}$ \\
\hline & {$[0.0836]$} & {$[0.0164]$} & {$[0.0534]$} & {$[0.0107]$} & {$[0.0651]$} \\
\hline \multirow[t]{2}{*}{ Household head } & -0.0986 & -0.0234 & -0.001 & $-0.0315^{* \star}$ & $-0.1843^{*}$ \\
\hline & {$[0.1020]$} & {$[0.0237]$} & {$[0.0039]$} & {$[0.0123]$} & {$[0.1009]$} \\
\hline \multirow[t]{2}{*}{ Married/nikoh } & -0.1019 & -0.0252 & 0.0012 & $-0.0283^{\star \star}$ & $-0.2578^{* \star}$ \\
\hline & [0.0709] & {$[0.0180]$} & {$[0.0045]$} & {$[0.0120]$} & {$[0.0530]$} \\
\hline \multirow[t]{2}{*}{ Age } & 0.0087 & 0.0021 & 0.0002 & 0.0055 & 0.0299 \\
\hline & {$[0.1083]$} & {$[0.0263]$} & {$[0.0020]$} & {$[0.0158]$} & [0.0783] \\
\hline \multirow[t]{2}{*}{ Age-square } & 0 & 0 & 0 & 0 & -0.0002 \\
\hline & {$[0.0017]$} & {$[0.0004]$} & {$[0.0000]$} & {$[0.0002]$} & {$[0.0012]$} \\
\hline \multirow[t]{2}{*}{ Male } & $1.2524^{\star \star *}$ & $0.3106^{\star \star \star}$ & 1.9879 & $0.3371^{\star \star \star}$ & -4.0126 \\
\hline & {$[0.0650]$} & {$[0.0141]$} & {$[2.4548]$} & {$[0.0090]$} & {$[3.7482]$} \\
\hline \multirow[t]{2}{*}{ Lives in rural areas } & $0.1726^{\star *}$ & $0.0418^{\star \star}$ & 0.0042 & $0.0334^{\star \star \star}$ & 0.0051 \\
\hline & {$[0.0808]$} & {$[0.0195]$} & {$[0.0152]$} & {$[0.0087]$} & {$[0.0427]$} \\
\hline \multirow[t]{2}{*}{ Lives in Tajikistan } & 0.0028 & 0.0007 & 0.0152 & $0.0686^{* \star *}$ & $-0.3484^{\star \star *}$ \\
\hline & [0.1056] & {$[0.0257]$} & [0.0549] & {$[0.0127]$} & {$[0.0667]$} \\
\hline \multirow[t]{2}{*}{ Lives in Uzbekistan } & -0.1484 & -0.0368 & 0.0098 & $0.0421^{* * *}$ & $-0.3623^{* * *}$ \\
\hline & {$[0.1035]$} & {$[0.0259]$} & {$[0.0356]$} & {$[0.0158]$} & {$[0.0701]$} \\
\hline \multirow[t]{2}{*}{ Number of children age $<18$} & 0.0015 & 0.0004 & -0.0002 & -0.0011 & 0.0032 \\
\hline & {$[0.0221]$} & {$[0.0054]$} & {$[0.0008]$} & {$[0.0027]$} & {$[0.0124]$} \\
\hline \multirow[t]{2}{*}{ Female headed household } & $-0.1481^{*}$ & $-0.0346^{*}$ & -0.001 & 0.0046 & 0.0843 \\
\hline & {$[0.0813]$} & {$[0.0181]$} & {$[0.0040]$} & {$[0.0166]$} & {$[0.0775]$} \\
\hline \multirow[t]{2}{*}{ Household consumption: second quintile } & -0.1219 & -0.029 & 0.0009 & -0.0027 & -0.0745 \\
\hline & {$[0.0801]$} & {$[0.0185]$} & {$[0.0034]$} & {$[0.0133]$} & {$[0.0622]$} \\
\hline \multirow[t]{2}{*}{ Household consumption: third quintile } & $-0.2335^{* \star *}$ & $-0.0544^{* \star *}$ & -0.0018 & $-0.0328^{* *}$ & $-0.1411^{* *}$ \\
\hline & {$[0.0847]$} & {$[0.0184]$} & {$[0.0066]$} & {$[0.0131]$} & {$[0.0626]$} \\
\hline \multirow[t]{2}{*}{ Household consumption: fourth quintile } & $-0.2889^{* * *}$ & $-0.0663^{* \star *}$ & -0.0009 & $-0.0286^{* *}$ & $-0.1633^{* *}$ \\
\hline & {$[0.0890]$} & {$[0.0188]$} & {$[0.0037]$} & {$[0.0137]$} & {$[0.0637]$} \\
\hline \multirow[t]{2}{*}{ Household consumption: fifth quintile } & $-0.2552^{\star \star \star}$ & $-0.0590^{* \star *}$ & -0.0016 & $-0.0255^{*}$ & -0.0979 \\
\hline & {$[0.0805]$} & {$[0.0172]$} & {$[0.0060]$} & {$[0.0135]$} & {$[0.0651]$} \\
\hline \multirow{2}{*}{$\begin{array}{l}\text { Household's share of tertiary educated } \\
\text { adults age }>46\end{array}$} & $0.2103^{\star *}$ & $0.0511^{* *}$ & 0.0038 & $0.0612^{\star \star \star}$ & $0.2403^{\star \star \star}$ \\
\hline & {$[0.0898]$} & {$[0.0221]$} & {$[0.0138]$} & {$[0.0141]$} & {$[0.0615]$} \\
\hline \multirow[t]{2}{*}{ Community's migrant network age $>46$} & $3.7565^{* \star *}$ & $0.9130^{\star * \star}$ & 0.0674 & $0.6373^{\star \star \star}$ & $0.8917^{\star \star \star}$ \\
\hline & {$[0.5876]$} & {$[0.1436]$} & {$[0.2406]$} & {$[0.0604]$} & {$[0.2780]$} \\
\hline \multirow[t]{2}{*}{ Constant } & -1.8167 & & -2.0145 & & \\
\hline & [1.6940] & & [2.4515] & & \\
\hline
\end{tabular}

Notes: Likelihood-ratio test of Insigma $2=0: X^{2}(18)=242.64$; Prob $>X^{2}=0.0000 .{ }^{*} p<0.1 ;{ }^{* *} p<0.05 ;{ }^{* \star *} p<0.01$. Standard errors are in brackets and clustered. Survey weights are used only in the Probit model by population survey units and survey strata. 
The variable on a share of migrants among the adult population with age 47 and above in the survey's population sampling unit is positively significantly correlated with the decision to migrate. The variable was created for the elder group of the population who studied during the Soviet era but decided to migrate after the collapse of the Soviet Union due to structural economic changes and emerging higher-paid employment opportunities in resource-rich destination countries. The community migrant network for this elderly population group makes it a good instrument to test the endogeneity of the migration decision with respect to the decision to acquire professional education.

It is likely that there are other community effects, such as access to education, labor market opportunities, and so on, which impact decisions to acquire professional education and/ or to migrate abroad. Individuals from some communities might have been historically less prone to obtain professional education. The sample data in Jobs, Skills, and Migration Surveys are grouped into PSU, which are geographical areas of a walkable size. Each PSU consists of most of 20 households. In Tajikistan, the sample of the capital city was boosted to estimate the energy use in Dushanbe. ${ }^{8}$ Because of disproportionately high representation of urban areas (because of the boosted survey sample for Dushanbe) and survey sampling, regression results obtained from an unweighted sample might result in biased estimates of causal effects because of existing heteroscedasticity (Solon et al., 2015). To check this, we estimated the heteroscedastic probit models for both decisions and tested the existence of heteroscedasticity in our sample data using the likelihood-ratio test. The $X^{2}(16)$ test statistic is 89.59 for the education decision regression and the $X^{2}(18)$ test statistic is 242.64 for the migration decision regression; therefore, we reject the null hy pothesis of homoscedasticity at the 0.01 significance level and proceed with the survey weights in our regression analysis. The marginal effect of being a former or current migrant on the decision of tertiary education and the marginal effect of having the tertiary education on the decision of migration from heteroscedastic probit regressions are still negative and are statistically significant at the 0.01 significance level.

We further analyze the choice between migration and education using Ordered Probit for three types of education, namely, secondary or less, vocational, and tertiary. The coefficient estimates of the model and marginal effects for each category of education are reported in Table 5. The results suggest an inverted- $U$ relationship between the migration decision and educational choice. The marginal effects of migration on educational choice are positive and statistically significant for the secondary general education level and decrease with professional (vocational and tertiary) education. Being a migrant is positively correlated with nonprofessional education but is negatively correlated with any professional education.

Other factors suggest that being a household head decreases the probability of being in the category of secondary or less education and additively increases the probability of being in professional education. Similarly, men have more access to professional education than women do. Living in rural areas increases additively the probability of being in the category of nonprofessional education and reduces the probability of being in professional education categories. In comparison to Kyrgyzstan, Tajikistan and Uzbekistan show higher attainment of lower secondary and general secondary education, and lower attainment of professional education. The number of children in the household increases additively the probability of being in the

8 https://microdata.worldbank.org/index.php/catalog/2813/download/39843 
Table 5 Ordered probit of the choice of education

\begin{tabular}{|c|c|c|c|c|}
\hline \multirow[t]{2}{*}{ Completed or acquiring education } & \multirow[t]{2}{*}{ Coefficients } & \multicolumn{3}{|c|}{ Marginal effects } \\
\hline & & Secondary or less & Vocational & Tertiary \\
\hline \multirow[t]{2}{*}{ Former or current migrant } & $-0.2227^{\star \star \star}$ & $0.0765^{\star \star \star}$ & $-0.0365^{\star \star \star}$ & $-0.0401^{\star \star \star}$ \\
\hline & {$[0.0640]$} & {$[0.0216]$} & {$[0.0112]$} & {$[0.0108]$} \\
\hline \multirow[t]{2}{*}{ Household head } & $0.3708^{\star \star \star}$ & $-0.1311^{\star \star \star}$ & $0.0502^{\star \star \star}$ & $0.0809^{\star \star \star}$ \\
\hline & {$[0.0759]$} & {$[0.0273]$} & {$[0.0098]$} & {$[0.0183]$} \\
\hline \multirow[t]{2}{*}{ Married/nikoh } & 0.0788 & -0.0272 & 0.0125 & 0.0147 \\
\hline & {$[0.0544]$} & {$[0.0186]$} & {$[0.0088]$} & [0.0099] \\
\hline \multirow[t]{2}{*}{ Age } & -0.0248 & 0.0086 & -0.0039 & -0.0048 \\
\hline & {$[0.0966]$} & {$[0.0336]$} & {$[0.0152]$} & {$[0.0184]$} \\
\hline \multirow[t]{2}{*}{ Age-square } & 0.0003 & -0.0001 & 0.0000 & 0.0001 \\
\hline & {$[0.0015]$} & {$[0.0005]$} & {$[0.0002]$} & {$[0.0003]$} \\
\hline \multirow[t]{2}{*}{ Male } & $0.1259^{\star}$ & $-0.0439^{\star \star \star}$ & $0.0198^{\star \star \star}$ & $0.0241^{\star \star}$ \\
\hline & {$[0.0488]$} & {$[0.0170]$} & {$[0.0077]$} & {$[0.0095]$} \\
\hline \multirow[t]{2}{*}{ Lives in rural area } & $-0.2881^{\star \star \star}$ & $0.1017^{\star \star \star}$ & $-0.0458^{\star \star \star}$ & $-0.0559^{\star \star \star}$ \\
\hline & {$[0.0730]$} & {$[0.0261]$} & {$[0.0119]$} & {$[0.0147]$} \\
\hline \multirow[t]{2}{*}{ Lives in Tajikistan } & $-0.6874^{\star \star \star}$ & $0.2247^{\star \star \star}$ & $-0.1213^{\star \star \star}$ & $-0.1034^{\star \star \star}$ \\
\hline & [0.1009] & {$[0.0300]$} & {$[0.0172]$} & {$[0.0147]$} \\
\hline \multirow[t]{2}{*}{ Lives in Uzbekistan } & $-0.3987^{\star \star \star}$ & $0.1372^{\star \star \star}$ & $-0.0534^{\star \star \star}$ & $-0.0837^{\star \star \star}$ \\
\hline & {$[0.0969]$} & {$[0.0323]$} & {$[0.0101]$} & {$[0.0231]$} \\
\hline \multirow[t]{2}{*}{ Number of children age $<18$} & $-0.0392^{\star}$ & $0.0136^{\star \star}$ & $-0.0061^{\star}$ & $-0.0075^{\star \star}$ \\
\hline & {$[0.0196]$} & {$[0.0068]$} & {$[0.0032]$} & {$[0.0036]$} \\
\hline \multirow[t]{2}{*}{ Female headed household } & -0.1485 & 0.0510 & -0.0244 & -0.0265 \\
\hline & {$[0.1113]$} & {$[0.0375]$} & {$[0.0190]$} & {$[0.0186]$} \\
\hline \multirow[t]{2}{*}{ Household consumption: second quintile } & 0.1441 & $-0.0501^{\star}$ & $0.0214^{\star}$ & 0.0287 \\
\hline & {$[0.0864]$} & {$[0.0299]$} & {$[0.0125]$} & {$[0.0176]$} \\
\hline \multirow[t]{2}{*}{ Household consumption: third quintile } & $0.3901^{\star \star \star}$ & $-0.1365^{\star \star \star}$ & $0.0534^{\star \star \star}$ & $0.0831^{\star \star \star}$ \\
\hline & {$[0.0670]$} & {$[0.0233]$} & {$[0.0087]$} & {$[0.0158]$} \\
\hline \multirow[t]{2}{*}{ Household consumption: fourth quintile } & $0.4938^{\star \star \star}$ & $-0.1740^{\star \star \star}$ & $0.0653^{\star \star \star}$ & $0.1087^{\star \star \star}$ \\
\hline & {$[0.0794]$} & {$[0.0277]$} & {$[0.0082]$} & {$[0.0211]$} \\
\hline \multirow[t]{2}{*}{ Household consumption: fifth quintile } & $0.5948^{\star \star \star}$ & $-0.2113^{\star \star \star}$ & $0.0761^{\star \star \star}$ & $0.1352^{\star \star \star}$ \\
\hline & {$[0.0740]$} & {$[0.0255]$} & {$[0.0079]$} & {$[0.0205]$} \\
\hline \multirow{2}{*}{$\begin{array}{l}\text { Household's share of tertiary educated } \\
\text { adults age }>46\end{array}$} & $0.7435^{\star \star \star}$ & $-0.2584^{\star \star \star}$ & $0.1162^{\star \star \star}$ & $0.1422^{\star \star \star}$ \\
\hline & {$[0.0834]$} & [0.0269] & {$[0.0136]$} & {$[0.0164]$} \\
\hline \multirow[t]{2}{*}{ cut1 } & -0.3322 & & & \\
\hline & {$[1.5271]$} & & & \\
\hline \multirow[t]{2}{*}{ cut2 } & 0.6924 & & & \\
\hline & [1.5255] & & & \\
\hline Observations & 803 & & & \\
\hline
\end{tabular}

${ }^{\star} p<0.1 ;{ }^{\star \star} p<0.05 ;{ }^{* \star \star} p<0.01$.

Notes: Standard errors are in brackets and clustered using the survey weights by population survey units and survey strata. 
category of nonprofessional education and reduces it for professional education. Dummy variables on consumption quintiles indicate the positive relationship between consumption and professional education. With an increase in consumption, the chances of being in the category of nonprofessional education decrease. Finally, having elder members of the household with professional education also increases additively the probability of being in categories with professional education and decreases the probability of being in the nonprofessional education category.

An issue with our regression analysis is the potential endogeneity of schooling and migration: perhaps, the decision on schooling is taken simultaneously with the migration decision. If this is the case, the estimated effects may be biased. To account for endogeneity, we use the instrumented variable Bivariate Probit model, where the structural equation is for the tertiary education decision and the reduced form equation is the migration decision. We will look at this in Table 6.

The excluded explanatory variable in the equation of the tertiary education decision is the community's migrant network variable as the share of current and former migrants relative to the community population age 47 and above. We believe that this is a good proxy measure of the incentives to migrate for younger migrants in each community. The countries experienced large economic and political shock after the collapse of the Soviet Union in 1991. Incentives affecting professional education and migration decisions changed significantly. After the collapse, individuals and households faced economic downtown, civil war (in Tajikistan), economic restructuring, broken linkages between enterprises, raised unemployment, and so on, all working to increase intercountry wages differentials among the labor abundant and oilrich countries. Those aged 47 years and above made their decisions on professional education based on factors and conditions during the Soviet period when migration was strictly controlled/prohibited. Their decision to migrate was then driven by post-collapse economic shock or increased unemployment. On the other hand, 25-39-year-old adults made their decisions about professional education having the option at the time to migrate to countries to work at nonprofessional occupations with higher wages. Younger migrants might make use of migrant social networks in its various forms, including friendship, neighboring and family ties, in job search, assimilation, and sending remittances. Older migrants in receiving countries attract their relatives, friends, and fellow villagers, providing necessary information and support.

The tertiary education decision equation and the migration equation estimates are from an instrumental variable Bivariate Probit based on Maximum Likelihood Estimation and are reported in Table 6. The coefficients on the community's migrant network strongly predict decisions on migration. The coefficient on the corresponding variable is positive and statistically significant at the 0.01 significance level. This result from the migration decision equation estimation indicates that the share of migrants of age 47 and above in the community is causally related to the decision of 25-39-year adults about migrating abroad for work. Migrant networks reduce migration costs; they provide information about earnings and employment opportunities abroad, and financial support to new migrants (Bauer et al., 2007, 2009). After controlling for the endogeneity of the decisions about migrating, the estimate on former or current migrants shows a negative relationship that is statistically different from 0 at the 0.1 significance level in deciding whether to acquire tertiary education. Other significant effects on tertiary education, which were defined in the probit model for the equation of tertiary education 
Table 6 Instrumented bivariate probit and two-stage least squares IV regressions on choices of migration and tertiary education

\begin{tabular}{|c|c|c|c|c|c|}
\hline & \multicolumn{3}{|c|}{ Instrumented bivariate probit } & \multicolumn{2}{|c|}{ Two-stage least squares } \\
\hline & \multicolumn{2}{|c|}{ Tertiary education } & \multirow{2}{*}{$\begin{array}{c}\text { Former or cur- } \\
\text { rent migrant }\end{array}$} & \multirow{2}{*}{$\begin{array}{c}\begin{array}{c}2^{\text {nd }} \text { stage: } \text { Ter- } \\
\text { tiary education }\end{array} \\
\text { Coefficients }\end{array}$} & \multirow{2}{*}{$\begin{array}{c}\begin{array}{c}1^{\text {st }} \text { stage: former or } \\
\text { current migrant }\end{array} \\
\text { Coefficients }\end{array}$} \\
\hline & $\begin{array}{l}\text { Coeffi- } \\
\text { cients }\end{array}$ & $\begin{array}{l}\text { Marginal } \\
\text { effects }^{\mathrm{a}}\end{array}$ & & & \\
\hline \multirow[t]{2}{*}{$\begin{array}{l}\text { Former or current } \\
\text { migrant }\end{array}$} & $-0.7078^{\star}$ & -0.1417 & & $-0.2190^{\star \star \star}$ & \\
\hline & {$[0.3674]$} & {$[0.1027]$} & & {$[0.0726]$} & \\
\hline \multirow[t]{2}{*}{ Household head } & $0.3127^{\star \star \star}$ & $0.0849^{\star \star}$ & -0.1319 & $0.0665^{\star \star \star}$ & $-0.0484^{\star}$ \\
\hline & {$[0.1118]$} & {$[0.0362]$} & {$[0.0984]$} & {$[0.0205]$} & {$[0.0269]$} \\
\hline \multirow[t]{2}{*}{ Married/nikoh } & 0.0604 & 0.0171 & -0.1107 & 0.0093 & -0.0217 \\
\hline & {$[0.0709]$} & {$[0.0174]$} & {$[0.0724]$} & [0.0153] & [0.0183] \\
\hline \multirow[t]{2}{*}{ Age } & 0.1215 & 0.0287 & -0.0025 & 0.0288 & -0.0040 \\
\hline & {$[0.1130]$} & {$[0.0279]$} & {$[0.1154]$} & [0.0213] & {$[0.0253]$} \\
\hline \multirow[t]{2}{*}{ Age-square } & -0.0021 & -0.0005 & 0.0002 & -0.0005 & 0.0001 \\
\hline & {$[0.0018]$} & {$[0.0004]$} & {$[0.0018]$} & {$[0.0003]$} & {$[0.0004]$} \\
\hline \multirow[t]{2}{*}{ Male } & $0.3619^{\star \star \star}$ & $0.0485^{\star \star \star}$ & $1.2351^{\star \star \star}$ & $0.0964^{\star \star \star}$ & $0.315^{\star \star \star}$ \\
\hline & {$[0.1318]$} & {$[0.0187]$} & {$[0.0643]$} & {$[0.0255]$} & {$[0.0146]$} \\
\hline \multirow[t]{2}{*}{ Lives in rural areas } & $-0.3004^{\star \star \star}$ & $-0.0776^{\star \star}$ & $0.1928^{\star \star}$ & $-0.0599^{\star \star \star}$ & $0.0516^{\star \star \star}$ \\
\hline & {$[0.0972]$} & {$[0.0330]$} & {$[0.0800]$} & [0.0112] & {$[0.0138]$} \\
\hline \multirow[t]{2}{*}{ Lives in Tajikistan } & $-0.5038^{\star \star \star}$ & $-0.1052^{\star \star \star}$ & 0.0370 & $-0.1370^{\star \star \star}$ & 0.0248 \\
\hline & {$[0.1128]$} & {$[0.0271]$} & {$[0.1111]$} & {$[0.0158]$} & {$[0.0161]$} \\
\hline \multirow[t]{2}{*}{ Lives in Uzbekistan } & $-0.9079^{\star \star \star}$ & $-0.2404^{\star \star \star}$ & -0.0695 & $-0.2230^{\star \star \star}$ & -0.0063 \\
\hline & {$[0.1042]$} & {$[0.0467]$} & [0.1035] & {$[0.0138]$} & {$[0.0137]$} \\
\hline \multirow{2}{*}{$\begin{array}{l}\text { Number of children } \\
\text { age }<18\end{array}$} & -0.0298 & -0.0071 & 0.0040 & $-0.0084^{\star \star}$ & 0.0005 \\
\hline & {$[0.0254]$} & {$[0.0061]$} & {$[0.0229]$} & {$[0.0035]$} & {$[0.0049]$} \\
\hline \multirow{2}{*}{$\begin{array}{l}\text { Female headed house- } \\
\text { hold }\end{array}$} & $-0.1845^{\star}$ & -0.0372 & $-0.1361^{\star}$ & $-0.0348^{\star}$ & $-0.0362^{\star}$ \\
\hline & {$[0.1112]$} & {$[0.0246]$} & {$[0.0812]$} & {$[0.0181]$} & {$[0.0216]$} \\
\hline \multirow{2}{*}{$\begin{array}{l}\text { Household consump- } \\
\text { tion: second quintile }\end{array}$} & 0.0214 & 0.0088 & -0.1237 & -0.0084 & -0.0269 \\
\hline & {$[0.0829]$} & {$[0.0214]$} & {$[0.0796]$} & {$[0.0128]$} & [0.0212] \\
\hline \multirow{2}{*}{$\begin{array}{l}\text { Household consump- } \\
\text { tion: third quintile }\end{array}$} & $0.3813^{\star \star \star}$ & $0.1056^{\star \star \star}$ & $-0.2615^{\star \star \star}$ & $0.0556^{\star \star \star}$ & $-0.0644^{\star \star \star}$ \\
\hline & {$[0.1174]$} & {$[0.0368]$} & {$[0.0831]$} & {$[0.0167]$} & {$[0.0205]$} \\
\hline \multirow{2}{*}{$\begin{array}{l}\text { Household consump- } \\
\text { tion: fourth quintile }\end{array}$} & $0.4161^{\star \star \star}$ & $0.1186^{\star \star \star}$ & $-0.3313^{\star \star \star}$ & $0.0613^{\star \star \star}$ & $-0.0802^{\star \star \star}$ \\
\hline & {$[0.1088]$} & {$[0.0436]$} & [0.0893] & {$[0.0179]$} & {$[0.0211]$} \\
\hline \multirow{2}{*}{$\begin{array}{l}\text { Household consump- } \\
\text { tion: fifth quintile }\end{array}$} & $0.5806^{\star \star \star}$ & $0.1671^{\star \star \star}$ & $-0.3149^{\star \star \star}$ & $0.1070^{\star \star \star}$ & $-0.0771^{\star \star \star}$ \\
\hline & {$[0.1061]$} & {$[0.0432]$} & [0.0793] & {$[0.0185]$} & {$[0.0217]$} \\
\hline \multirow{2}{*}{$\begin{array}{l}\text { Household's share } \\
\text { of tertiary educated } \\
\text { adults age }>46\end{array}$} & $0.7379 * \star \star$ & $0.1696^{\star \star \star}$ & 0.1354 & $0.1700^{\star \star \star}$ & 0.0293 \\
\hline & [0.0936] & [0.0453] & {$[0.0848]$} & [0.0184] & [0.0195] \\
\hline \multirow{2}{*}{$\begin{array}{l}\text { Community's migrant } \\
\text { network age }>46\end{array}$} & & -0.1122 & $3.8201^{\star \star \star}$ & & $1.0310^{\star \star \star}$ \\
\hline & & [0.1855] & {$[0.6203]$} & & {$[0.0982]$} \\
\hline
\end{tabular}


Table 6 Continue

\begin{tabular}{|c|c|c|c|c|c|}
\hline & \multicolumn{3}{|c|}{ Instrumented bivariate probit } & \multicolumn{2}{|c|}{ Two-stage least squares } \\
\hline & \multicolumn{2}{|c|}{ Tertiary education } & \multirow{2}{*}{$\begin{array}{c}\text { Former or cur- } \\
\text { rent migrant } \\
\text { Coefficients }\end{array}$} & \multirow{2}{*}{$\begin{array}{c}2^{\text {nd }} \text { stage: Ter- } \\
\text { tiary education } \\
\text { Coefficients }\end{array}$} & \multirow{2}{*}{$\begin{array}{c}\mathbf{1}^{\text {st }} \text { stage: former or } \\
\text { current migrant } \\
\text { Coefficients }\end{array}$} \\
\hline & $\begin{array}{l}\text { Coeffi- } \\
\text { cients }\end{array}$ & $\begin{array}{l}\text { Marginal } \\
\text { effects }^{\mathrm{a}}\end{array}$ & & & \\
\hline \multirow[t]{2}{*}{ Constant } & & & & -0.1330 & 0.0529 \\
\hline & & & & {$[0.3340]$} & {$[0.3960]$} \\
\hline R-squared & & & & 0.1050 & 0.1750 \\
\hline \multirow[t]{2}{*}{$\operatorname{atanh} \rho$} & 0.1636 & & & & \\
\hline & {$[0.2225]$} & & & & \\
\hline \multirow[t]{2}{*}{$\rho$} & 0.1621 & & & & \\
\hline & {$[0.2166]$} & & & & \\
\hline Observations & & 8037 & & & 037 \\
\hline
\end{tabular}

Notes: Standard errors are in brackets and clustered using the survey weights by population survey units and survey strata. ${ }^{*} p<0.1 ;{ }^{* *} p<0.05 ;{ }^{* \star *} p<0.01$.

The estimate of the average population effect of being a former or current migrant on the decision of tertiary education in the Bivariate Probit is -0.1125 with a standard error of 0.0026 .

above, remain the same. Our estimation shows that the individual's expectation or decision to migrate impacts the tertiary education decision. Wooldridge (2010) suggested estimating the average population effect (APE) in the bivariate probit model. The APE of being a former or current migrant on the decision to obtain tertiary education is -0.1125 with a standard error of 0.0026. Next, we compare it with the APE from the linear probability model. ${ }^{9}$

An alternative specification is the linear probability model, the instrumental variable regression based on two-stage least square estimation. These estimates are also reported in Table 6. The size of the APE of being a former or current migrant on the decision of tertiary education almost doubles in the linear probability model estimation, but it still shows a negative relationship with tertiary at the 0.01 significance level, after controlling for the endogeneity of the decisions about migrating. ${ }^{10}$

We performed the endogeneity test for instrumental variable linear regression with survey weights for both samples using the $C$ (GMM distance) test (Baum et al., 2007). The $C$ test reports statistics that are robust to different violations of conditional homoscedasticity. The null hypothesis is that the decision about migrating can be treated as exogenous. The reported $p$-value of the $C$ test is 0.0592 . This confirms that the decision on migration is endogenous at the 0.1 significance level.

9 We estimated the correlation between the error terms of equations of the bivariate probit model without survey sample weights with robust standard errors. The estimated value of $\rho$ is 0.0870 with standard error of 0.1160 which close to 0 and it becomes, statistically, significantly different from zero (0.3593 with standard error of 0.1507$)$ when we drop community migrant network from the migration decision equation. This suggests that including migrant network in the migration decision equation helps to reduce the correlation to 0 between unobservables that affect the migration decision and acquiring the tertiary education.

10 Linear probability model estimations produce biased, inconsistence estimates, and marginal effects (Horrace \& Oaxaca, 2006). Also see

http://www.mostlyharmlesseconometrics.com/2012/07/probit-better-than-lpm/ 
We conducted the under-identification tests, where the null hypothesis is the equation is under-identified, based on the Kleibergen-Paap rk LM statistic. The reported Kleibergen-Paap rk LM statistic is $\mathcal{X}^{2}(1)$, is equal to 94.38 , and the $p$-value is equal to 0 . This allows us to conclude that our estimating equations are identified. We also performed the weak identification test, where the null hypothesis is that our instrument is weak, using the Kleibergen-Paap $r k$ Wald F statistic. The test statistics are equal to 110.34, which are larger than Staiger and Stock's (1997) "rule of thumb" that the F statistics should be at least 10 for weak identification. ${ }^{11}$

\section{Conclusion}

Our analysis argues that with higher earnings for low-skilled labor in higher-income host countries, individuals may forgo higher education, opting to migrate abroad to work at unskilled occupations, especially when these occupations are paying multiples of their home pay. Such wage differentials may lead to the rejection of tertiary professional education and training by individuals in the migrants' home countries in expectation of migrating. Where the existence of high paying low-skilled jobs abroad reduces educational investment at home, this can give rise to forsaken schooling.

In our model, decisions over education and migration are reciprocally causal-an individual after completing compulsory schooling decides whether to forego professional schooling and migrate abroad for higher earnings. We estimated the impact of the migration decision on the decision to obtain tertiary education using an instrumental variable approach. We have already addressed several robustness issues centering on the possible endogeneity of migration and educational choices. Our thinking was to look for consistency and robustness in our estimates when using approaches that might expose, on their own, such biases. Our strategy was to first estimate a probit regression on the tertiary education decision (Table 3), do the probit regression on the migration decision (Table 4) and a more detailed analysis of the same with an ordered probit (Table 5). We directly take on the endogeneity issue between migration and tertiary education using the instrumented variable bivariate probit model (Table 6), as well as the instrumental variable regression based on two-stage least square estimation (Table 6). From an initial examination of sample statistics and onward through each estimation, we find the same consistent story of forsaken schooling.

Our empirical analysis of three former Soviet countries in Central Asia-Kyrgyzstan, Tajikistan, and Uzbekistan, suggests that these countries face a loss in human capital formation. These Republics have high general education completion rates (i.e., up to the stage of choosing to continue their schooling in professional studies or entering the labor force) and significant external migration involving a large share of their labor force. Existing wage differences, job availability, and the existence of regional free labor movement agreements between the Russian Federation and these Central Asian countries induced many young people to

11 A further concern might be that there is unobserved heterogeneity. We are estimating a nonlinear model, where we are interested in estimating not only parameters but also the partial effects. There might be two scenarios for the existence of the heterogeneity. The first is when the heterogeneity is independent of model's explanatory variables (a strong assumption); in this case estimating the partial effect gives us the same direction of the variable's effects as their scaled parameters. We estimated the heteroscedastic probit models and compared the marginal effects. The second is when the heterogeneity is related to the model's explanatory variables; in this case one can use the instrumental variable approach to control for endogeneity and estimate the system of equations to obtain the average population effect using bivariate probit or linear probability models. We have used all these estimation technics in our paper. 
forgo professional education, opting to migrate to Russia for high-paying unskilled work. The forsaken schooling phenomenon limits the extent to which these countries have been able to turn this youth bulge into their own demographic dividends. To the extent skills formation and education drive economic development, foregone schooling leaves these migrant-sending countries with less progress than they might otherwise have had toward building a knowledge-based economy.

\section{Declarations}

\section{Availability of data and material}

The datasets analyzed during the current study are available in the World Bank's microdata repository and on a request:

- World Bank, German Federal Enterprise for International Cooperation (GIZ). Tajikistan Jobs, Skills, and Migration Survey (JSMS) 2013, Public Use Files. Ref. TAJ_2013_JSMS_v01_M_v01_A_PUF. Dataset downloaded from https://microdata.worldbank.org/index.php/catalog/2813

- World Bank, German Federal Enterprise for International Cooperation (GIZ). Kyrgyz Republic Jobs Skills and Migration Survey (JSMS) 2013, Ref. KGZ_2013_JSMS_v01_M. Dataset downloaded from https://microdata.worldbank.org/index.php/catalog/2814

- World Bank, German Federal Enterprise for International Cooperation (GIZ). Uzbekistan Jobs, Skills, and Migration Survey (JSMS) 2013, available on a request. It is used with permission of the World Bank.

\section{Competing interests}

The authors declare that they have no competing interests.

\section{Authors' contributions}

Authors describe the new phenomenon of forsaken schooling in the relationship between migration and professional education, made all regression analyses with the data.

\section{Acknowledgment}

We thank the editor and referees for their insightful suggestions. This article does not necessary reflect OSIAF's views and policies.

\section{Funding}

Not applicable.

\section{References}

Abdulloev, I.; G. S., Epstein; I. N. Gang (2019): Schooling Forsaken: Education and Migration. IZA Discussion Paper No. 12088.

Acosta, P. (2006):. Labor Supply, School Attendance, and Remittances from International Migration: the Case of El Salvador. World Bank Policy Research Working Paper, 3903, World Bank.

Ahunov, M.; J. Kakhkharov; Z. Parpiev; I. Wolfson (2015): Socio-Economic Consequences of Labor Migration in Uzbekistan. Discussion Papers in Economics Economics: 201507, Griffith University, Department of Accounting, Finance and Economics.

Ajwad, M. I.; I. Abdulloev; R. Audy; S. Hut; J. de Laat; I. Kheyfets; J. Larrison; Z. Nikoloski; F. Torracchi (2014a): The Skills Road: Skills for Employability in Uzbekistan. World Bank, Washington, DC.

Ajwad, M. I.; J. de Laat; S. Hut; J. Larrison; I. Abdulloev; R. Audy; Z. Nikoloski; F. Torracchi, F. (2014b): The Skills Road: Skills for Employability in the Kyrgyz Republic. World Bank, Washington, DC.

Ajwad, M. I.; S. Hut; I. Abdulloev; R. Audy; J. de Laat; S. Kataoka; J. Larrison; Z. Nikoloski; F. Torracchi (2014c): The Skills Road: Skills for Employability in Tajikistan. World Bank, Washington, DC.

Amuedo-Dorantes, C.; S. Pozo (2010): Accounting for Remittance and Migration Effects on Children's Schooling. World Development 38(12), 1747-1759.

Bauer, T.; G. S. Epstein; I. N. Gang (2007): The Influence of Stocks and Flows on Migrants' Location Choices. Research in Labor Economics 26, 199-229. doi:10.1016/S0147-9121\%2806\%2926006-0.

Bauer, T.; G. S. Epstein; I. N. Gang (2009): Measuring Ethnic Linkages Among Migrants. International Journal of Manpower 30(1/2), 56-69. doi:10.1108/01437720910948393. 
Baum, Ch.; M. Schaffer; S. Stillman (2007): Enhanced routines for instrumental variables/generalized method of moments estimation and testing. Stata Journal 7(4), 465-506.

Beine, M.; F. Docquier; H. Rapoport (2001): Brain Drain and Economic Growth: Theory and Evidence. Journal of Development Economics 64(1), 275-289.

Beine, M.; F. Docquier; H. Rapoport (2008): Brain Drain and Human Capital Formation in Developing Countries: Winners and Losers. The Economic Journal 118(528), 631-652.

Bhagwati, J. N. (1984): Why are Services Cheaper in the Poor Countries? The Economic Journal 94(374), 279-286.

Bhagwati, J.; K. Hamada (1974): The Brain Drain, International Integration of Markets for Professionals and Unemployment: A Theoretical Analysis. Journal of Development Economics 1(1), 19-42.

Bredtmann, J.; F. M. Flores; S. Otten (2019): Remittances and the Brain Drain: Evidence from Microdata for Sub-Saharan Africa, Journal of Development Studies 55(7), 1455-1476. doi:10.1080/00220388.2018.14432 08.

Calero, C.; A. S. Bedi; R. Sparrow (2009): Remittances, Liquidity Constraints and Human Capital Investments in Ecuador. World Development 37(6), 1143-1154.

Co, C. Y.; I. N. Gang; M. S. Yun (2000): Returns to Returning. Journal of Population Economics 13(1), 57-79.

Dai, T.; X. Liu; B. Xie (2015): Brain Drain Reversal and Return Subsidy. Journal of Comparative Economics 43(2), 443-455

Danzer, A. M.; B. Dietz; K. Gatskova (2013): Tajikistan Household Panel Survey: Migration, Remittances and the Labor Market. Survey Report. Institute for East and Southeast European Studies, Regensburg.

Dimova, R.; G. S. Epstein; I. N. Gang (2015): Migration, Transfers and Child Labor. Review of Development Economics 19(3), 735-747.

Duryea, S.; A. Cox; M. Ureta (2003): Adolescents and Human Capital Formation. In Duryea, S.; A. Cox; M. Ureta (eds.), Critical Decisions at a Critical Age: Adolescents and Young Adults in Latin America. Inter-American Development Bank, 1-23.

Education, Audiovisual and Culture Executive Agency of the European Union (2017): Edit Overview of the Higher Education System in Partner Countries: Central Asia. https://publications.europa.eu/en/publication-detail/-/publication/3c728d8a-6144-11e7-8dc1-01aa75ed71a1 [Accessed 12 August 2019].

Edwards, A. C.; M. Ureta (2003): International Migration, Remittances, and Schooling: Evidence from El Salvador. Journal of Development Economics 72(2), 429-461.

Feldman, D. H.; I. N. Gang, (1990): Financial Development and the Price of Services. Economic Development and Cultural Change 38(2), 341-352.

Gao, X.; A. Kikkawa (2019): Evaluating the Impact of Remittances on Human Capital Investment in the Kyrgyz Republic. Manuscript, Cornell University -Dyson School.

Gatskova, K.; A. Ivlevs; B. Dietz (2019): Can Labor Emigration Affect the Education of Girls? Evidence from Tajikistan. Feminist Economics 25(3), 96-118. doi:10.1080/13545701.2019.1615101.

Grubel, H. B.; A. D. Scott (1966): International Flow of Human Capital. The American Economic Review 56(1/2), 268-274.

Hines, A. L.; N. B. Simpson (2018): Migration, Remittances and Human Capital Investment in Kenya. IZA Discussion Paper 11835.

Horrace, W. C.; R. L. Oaxaca (2006): Results on the Bias and Inconsistency of Ordinary Least Squares for the Linear Probability Model. Economics Letters 90(3), 321-327.

Kandel, W.; G. Kao (2001): The Impact of Temporary Labor Migration on Mexican Children's Educational Aspirations and Performance. International Migration Review 35(4), 1205-1231.

Karymshakov, K.; B. Sulaimanova (2019): The School-to-Work Transition, Overeducation and Wages of Youth in Kyrgyzstan. International Journal of Manpower 40(8), 1458-1481.

Kravis, I. B.; R. E. Lipsey (1983): Toward an Explanation of National Price Levels. Princeton Studies in International Finance, No. 52. Princeton, NJ, November 1983.

Kroeger, A.; K. Anderson (2014): Remittances and the Human Capital of Children: New Evidence from Kyrgyzstan During Revolution and Financial Crisis, 2005-2009. Journal of Comparative Economics 42(3), 770-785.

McKenzie, D.; H. Rapoport (2011): Can Migration Reduce Educational Attainment? Evidence from Mexico. Journal of Population Economics 24(4), 1331-1358.

Mountford, A. (1997): Can a Brain Drain be Good for Growth in the Source Economy? Journal of Development Economics, 53(2), 287-303.

Özden, Ç. G. (2006): Educated Migrants: Is there A Brain Waste? in: Özden, Ç. G.; M. Schiff (eds.), International Migration, Remittances, and the Brain Drain. Washington, DC: World Bank, 227-244.

Panagariya, A. (1988): A Theoretical Explanation of Some Stylized Facts of Economic Growth. The Quarterly Journal of Economics 10(3), 509-526.

Piracha, M.; T. Randazzo; F. Vadean (2013): Remittances and Occupational Outcomes of the Household Members Left-Behind. IZA Discussion Paper No. 7582. Available at SSRN: http://ssrn.com/abstract=2322087. 
Rocheva, A.; E. Varshaver (2018): Gender Dimension of Migration from Central Asia to the Russian Federation. Asia-Pacific Population Journal (32)2. doi:10.18356/e617261d-en.

Shakirov, M. (2009): Director. Migrant Express Parts 1-7. Radio Free Europe/Radio Liberty. https://www.rferl. org/p/5461.html [Accessed 14 January 2020].

Solon, G.; S. J. Haider; J. M. Wooldridge (2015): What Are We Weighting For? Journal of Human Resources 50 , 301-316.

Staiger, D.; J. Stock (1997): Instrumental Variables Regression with Weak Instruments. Econometrica, 65(3), 557-586. doi:10.2307/2171753.

Stark, O.; C. Helmenstein; A. Prskawetz (1997): A Brain Gain with a Brain Drain. Economics Letters 55(2), 227-234.

Stark, O.; C. Helmenstein; A. Prskawetz (1998): Human Capital Depletion, Human Capital Formation, and Migration: A Blessing or a "Curse"? Economics Letters 60(3), 363-367.

Stark, O.; Y. Wang (2002): Inducing Human Capital Formation: Migration as a Substitute for Subsidies. Journal of Public Economics 86(1), 29-46.

Wang, D.; A. Hagedorn; G. Chi (2019): Remittances and Household Spending Strategies: Evidence from the Life in Kyrgyzstan Study, 2011-2013. Journal of Ethnic and Migration Studies, 1-22.

Weiss, Y.; R. M. Sauer; M. Gotlibovski (2003): Immigration, Search, and Loss of Skill. Journal of Labor Economics 21(3), 557-591.

Wooldridge, J. M. (2010): Econometric Analysis of Cross Section and Panel Data. MIT Press.

Yamada, D. (2016): Negative Effect of Past Migration Experience on Education Investment: Evidence from Tajikistan. Available at SSRN: https://ssrn.com/abstract=2568964 or doi:10.2139/ssrn.2568964.

Yang, D. (2005): International Migration, Human Capital, and Entrepreneurship: Evidence from Philippine Migrants' Exchange Rate Shocks. World Bank Policy Research Working Paper 3578. The World Bank. 